\section{Pacific Northwest}

National Laboratory

Operated by Battelle for the

U.S. Department of Energy

\section{Slug Test Characterization Results for Multi-Test/Depth Intervals Conducted During the Drilling of CERCLA Operable Unit OU ZP-1 Wells 299- W10-33 and 299-W11-48}

D. R. Newcomer

September 2007

\author{
Prepared for the U.S. Department of Energy
} under Contract DE-AC05-76RL01830 


\section{LIMITED DISTRIBUTION NOTICE}

This document copy, since it is transmitted in advance of patent clearance, is made available in confidence solely for use in performance of work under contracts with the U.S. Department of Energy. This document is not to be published nor its contents otherwise disseminated or used for purposes other than specified above before patent approval for such release or use has been secured, upon request, from Intellectual Property Services, Pacific Northwest National Laboratory, Richland, Washington 99352. 


\title{
Slug Test Characterization Results for Multi- Test/Depth Intervals Conducted During the Drilling of CERCLA Operable Unit OU ZP-1 Wells 299-W10-33 and 299-W11-48
}

\author{
D. R. Newcomer
}

September 2007

Prepared for the U.S. Department of Energy under Contract DE-AC05-76RL01830

Pacific Northwest National Laboratory

Richland, Washington 99352 


\section{Summary}

Slug-test results obtained from single and multiple, stress-level slug tests conducted during drilling and borehole advancement provide detailed hydraulic conductivity information at two Hanford Site Operable Unit (OU) ZP-1 test well locations. The individual test/depth intervals were generally sited to provide hydraulic-property information within the upper $\sim 10 \mathrm{~m}$ of the unconfined aquifer (i.e., Ringold Formation, Unit 5). These characterization results complement previous and ongoing drill-and-test characterization programs at surrounding 200-West and -East Area locations (see Figure S.1). ${ }^{\text {(a) }}$

An analysis of the slug-test results indicates calculated average test-interval estimates of hydraulic conductivities ranging between 1.24 and $15.7 \mathrm{~m} /$ day. The ZP-1 well hydraulic-conductivity estimates were derived for test-interval sections that ranged from 1.0 to $1.6 \mathrm{~m}$ in length. The highest hydraulicconductivity estimates were obtained for a single zone tested at well 299-W10-33 (i.e., range of 13.0 to $17.3 \mathrm{~m} /$ day), which is the southernmost ZP-1 well tested. These values bracket the reported 200-West Area geometric mean value ( $3.08 \mathrm{~m} /$ day) for recent slug tests conducted at 30 monitor-well sites completed within the upper part (i.e., upper $10 \mathrm{~m}$ ) of the unconfined aquifer in the 200-West Area (Spane et al., 2001a, 2001b, 2002, 2003; Spane and Newcomer 2004).

\section{References}

Spane FA. Jr, PD Thorne, and DR Newcomer. 2001a. Results of detailed hydrologic characterization tests - FY 1999, PNNL-13378, Pacific Northwest National Laboratory, Richland, Washington.

Spane FA, Jr, PD Thorne, and DR Newcomer. 2001b. Results of detailed hydrologic characterization tests - FY 2000. PNNL-13514, Pacific Northwest National Laboratory, Richland, Washington.

Spane FA, Jr, PD Thorne, and DR Newcomer. 2002. Results of detailed hydrologic characterization tests - FY 2001. PNNL-14113, Pacific Northwest National Laboratory, Richland, Washington.

Spane FA, Jr, PD Thorne, and DR Newcomer. 2003. Results of detailed hydrologic characterization tests - FY 2002. PNNL-14186, Pacific Northwest National Laboratory, Richland, Washington.

(a) Spane FA. 2003. Slug Test Characterization Results for Multi- Test/Depth Intervals Conducted During the Drilling of WMA-C Well 299-E27-22 (C4124). Letter report to Jane Borghese (Fluor Hanford, Inc.), October 8, 2003.

Spane FA. 2005a. Slug Test Characterization Results for Multi-Test/Depth Intervals Conducted During the Drilling of WMA-BX-BY Well 299-E33-49. Letter report to Jane Borghese (Fluor-Hanford, ORP) January 10, 2005.

Spane FA. 2005b. Slug Test Characterization Results for Multi-Test/Depth Intervals Conducted During the Drilling of CERCLA Operable Unit UP-1 Wells 299-W19-48, 699-30-66, and 699-36-70B. Letter report to Mark Byrnes (Fluor-Hanford, ORP) September 13, 2005.

Spane FA. 2005c. Slug Test Characterization Results for Multi-Test/Depth Intervals Conducted During the Drilling of CERCLA Operable Unit ZP-1 Wells 299-W11-43, 299-W15-50, and 299-W18-16. Letter report to Mark Byrnes (Fluor-Hanford, ORP) September 13, 2005. 


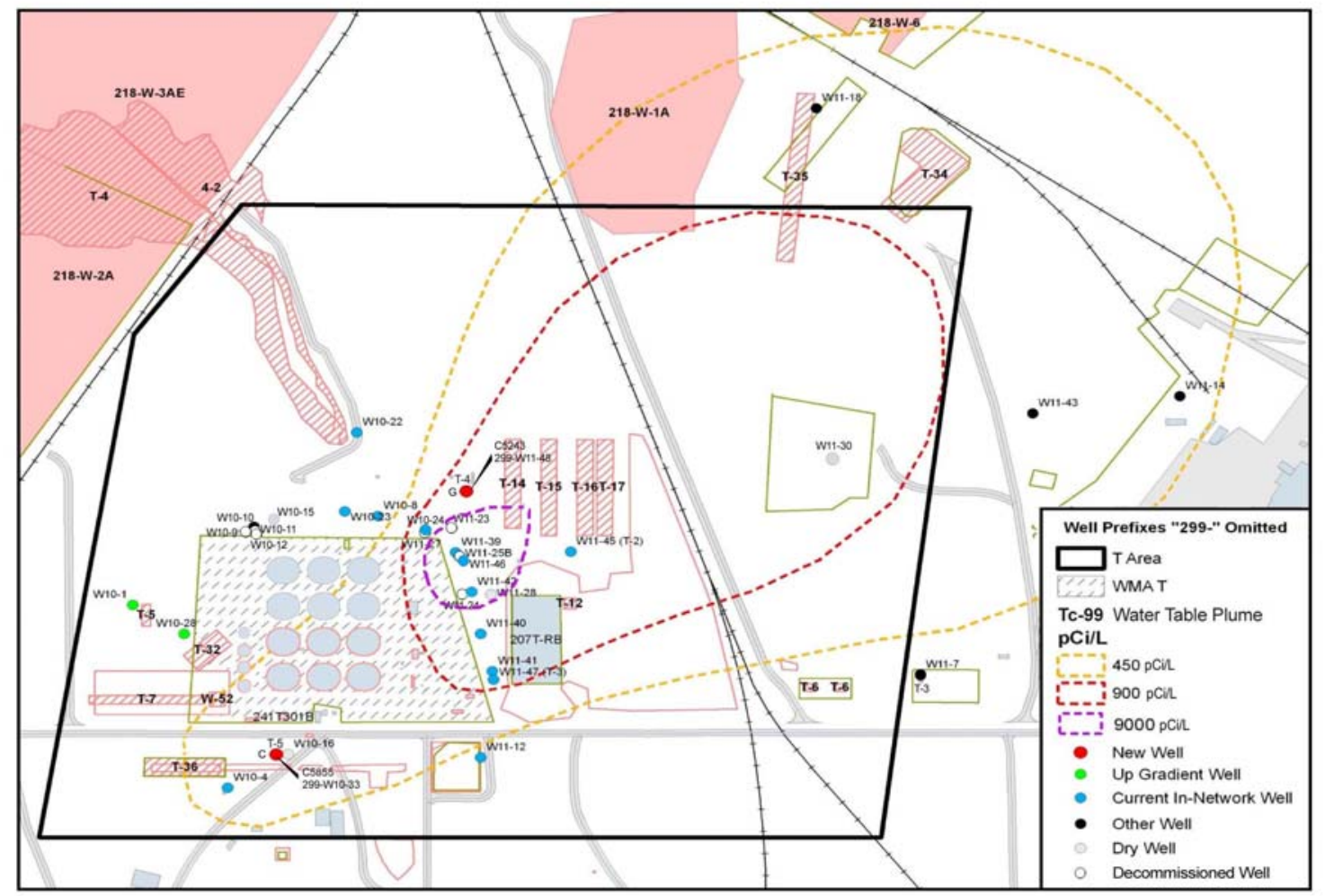

Figure S.1. Location Map Showing OU ZP-1 Test Well Sites 


\section{Contents}

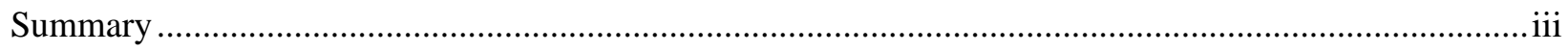

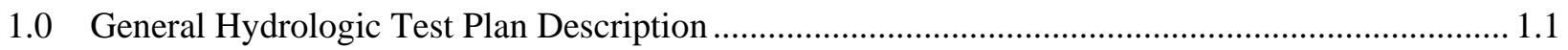

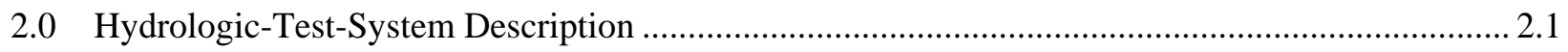

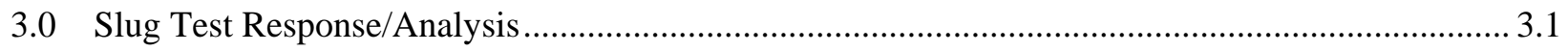

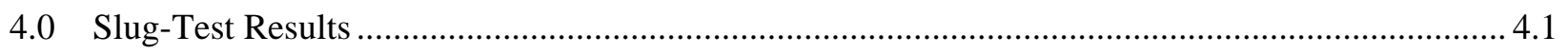

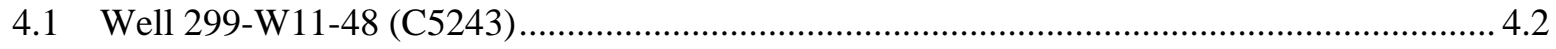

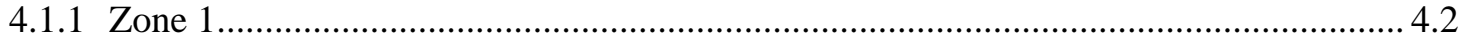

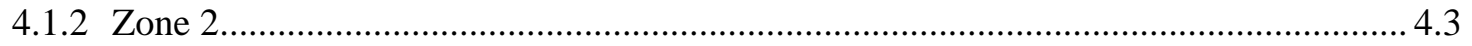

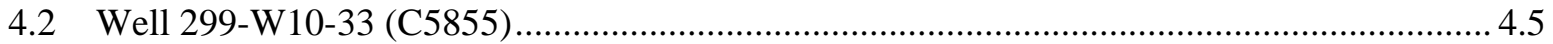

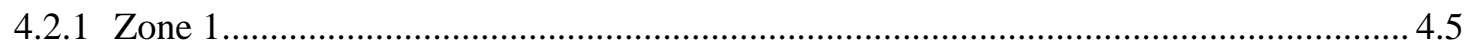

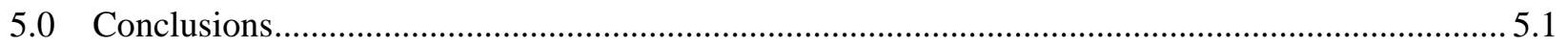

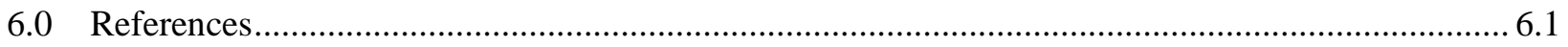

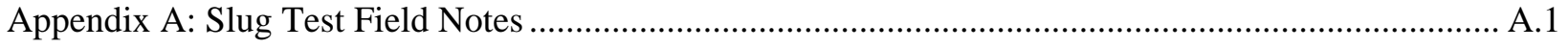

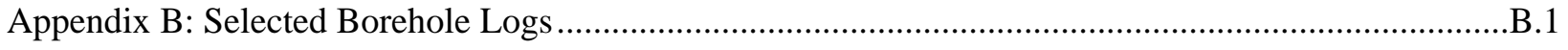

\section{Figures}

S.1 Location Map Showing OU ZP-1 Test Well Sites....................................................................... iv

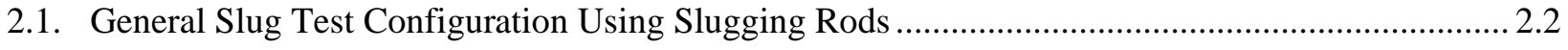

2.2. Packer/Well-Screen Assembly Dimensions ............................................................................... 2.3

3.1. Diagnostic Slug Test Response (taken from Spane et al. (2003a) ................................................ 3.2

3.2. Over-Damped Slug-Test Response as a Function of Test-Interval Hydraulic Conductivity ............. 3.3

4.1. Selected Slug Test Analysis Plot for Well 299-W11-48: (a) Diagnostic(top) and (b) TypeCurve Analysis Method (bottom) .............................................................................................. 4.4

4.2. Selected Slug-Test-Analysis Plot for Well 299-W11-48: (a) Diagnostic (top) and (b) TypeCurve Analysis Method (bottom) ........................................................................................... 4.6

4.3. Selected Slug Test Analysis Plot for Well 299-W10-33: Test Interval Zone 1 (Type-Curve Method)......

4.4. A High-Stress Slug Test Showing Slightly Critically Damped Behavior on a Semi-Log Plot for Test Interval Zone 1, Well 299-W10-33. 


\section{Tables}

4.1. Slug-Test Characteristics for Selected Test/Depth Intervals at Operable Unit ZP-1 Test

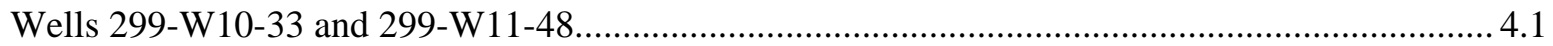

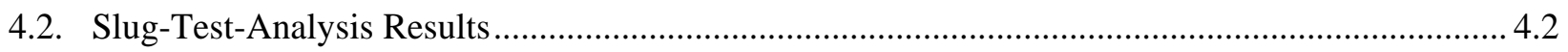




\subsection{General Hydrologic Test Plan Description}

The following discussion of the general hydrologic test plan is taken primarily from similar slug-test characterization-program descriptions presented previously in Spane. ${ }^{(a)}$ Hydrologic testing was implemented when the approximate targeted depth intervals within the unconfined aquifer were reached during drilling. To prepare the test zone for slug-test characterization, the packer/well-screen test assembly was lowered to the bottom of the borehole and the drill casing retracted, exposing an approximate 1.5-m open borehole section. The packer was then inflated to isolate the well-screened/test interval and the testing string from the inside of the drill casing.

A series of multiple, stress-level slug tests were attempted for each isolated test-interval section. The reason for using a multi-stress-level approach was to determine whether the associated slug-test responses exhibited either a variable or stress-level dependence. As noted in Butler (1998) and Spane et al. (2003b), tests exhibiting either variable or stress-level dependence can provide valuable information pertaining to the presence of a dynamic well skin or non-linear (i.e., turbulence) test-response conditions occurring within the test section. General slug-test stress levels applied during testing were designed to be within the range of $\sim 0.3$ to $0.5 \mathrm{~m}$ for lower stress tests and $\sim 1.0 \mathrm{~m}$ for higher stress tests. The slug tests were initiated using two slugging rods of different, known displacement volumes. Unfortunately, only one of the three test zones (i.e., Zone 1 at well 299-W10-33) was tested successfully using slugging rods with different displacement volumes. The second of the three test zones (i.e., Zone 2 at well 299-W11-48) was tested successfully at a low stress, but not at a high stress, and the third zone (i.e., Zone 1 at well 299W11-48) was tested successfully at a high stress, but not at a low stress.

For Zone 1, well 299-W10-33, three or more multi-stress slug tests were conducted successfully. Individual slug tests were fully recovered before depressing the fluid column to prepare the next slug test within the characterization sequence. A wide-range in recovery times was expected, based on an anticipated range in permeability conditions. For example, Spane et al. (2001a, 2001b, 2002, 2003a) and Spane and Newcomer (2004) report recovery times as rapid as $<15 \mathrm{sec}$ for high-permeability test intervals to $>5 \mathrm{~min}$ for lower permeability test zones for 200 -West Area wells. A description of the hydrologic test system used during slug-test characterization is provided in the following report section.

(a) Spane FA. 2003. Slug Test Characterization Results for Multi- Test/Depth Intervals Conducted During the Drilling of WMA-C Well 299-E27-22 (C4124). Letter report to Jane Borghese (Fluor Hanford, Inc.), October 8, 2003.

Spane FA. 2005a. Slug Test Characterization Results for Multi-Test/Depth Intervals Conducted During the Drilling of WMA-BX-BY Well 299-E33-49. Letter report to Jane Borghese (Fluor-Hanford, ORP) January 10, 2005.

Spane FA. 2005b. Slug Test Characterization Results for Multi-Test/Depth Intervals Conducted During the Drilling of CERCLA Operable Unit UP-1 Wells 299-W19-48, 699-30-66, and 699-36-70B. Letter report to Mark Byrnes (Fluor-Hanford, ORP) September 13, 2005.

Spane FA. 2005c. Slug Test Characterization Results for Multi-Test/Depth Intervals Conducted During the Drilling of CERCLA Operable Unit ZP-1 Wells 299-W11-43, 299-W15-50, and 299-W18-16. Letter report to Mark Byrnes (Fluor-Hanford, ORP) September 13, 2005. 


\subsection{Hydrologic-Test-System Description}

Figure 2.1 shows the general test-system configuration used for slug tests conducted during the drilling and testing of the ZP-1 wells with single-wall drill-casing strings. Slug tests were conducted using slugging rods for all test zones within single-wall drill casing wells 299-W10-33 and 299-W11-48. Features common to this test-system configuration include a downhole packer/well-screen test assembly and a downhole pressure transducer and surface datalogger system. The drill-casing strings used for borehole advancement during the drilling of the ZP-1 wells varied slightly for the respective well sites and had the following I.D./O.D. dimensions: well 299-W10-33: 0.248/0.273 m; and well 299-W15-48: $0.248 / 0.260 \mathrm{~m})$.

As shown in Figure 2.1, an inflatable packer was used to seal and isolate the test interval and testing string from the encompassing drill-casing area. A 20-slot, well-screen section was attached below the packer to maintain an open section for testing after retracting the drill casing. For testing at all ZP-1 well sites, one standard packer/well-screen assembly was used: 3.05-m long, 0.1016-m I.D. well-screen (Figure 2.2). A strain-gauge pressure transducer was installed within the test-casing string to monitor downhole test-interval response before and during slug testing. 


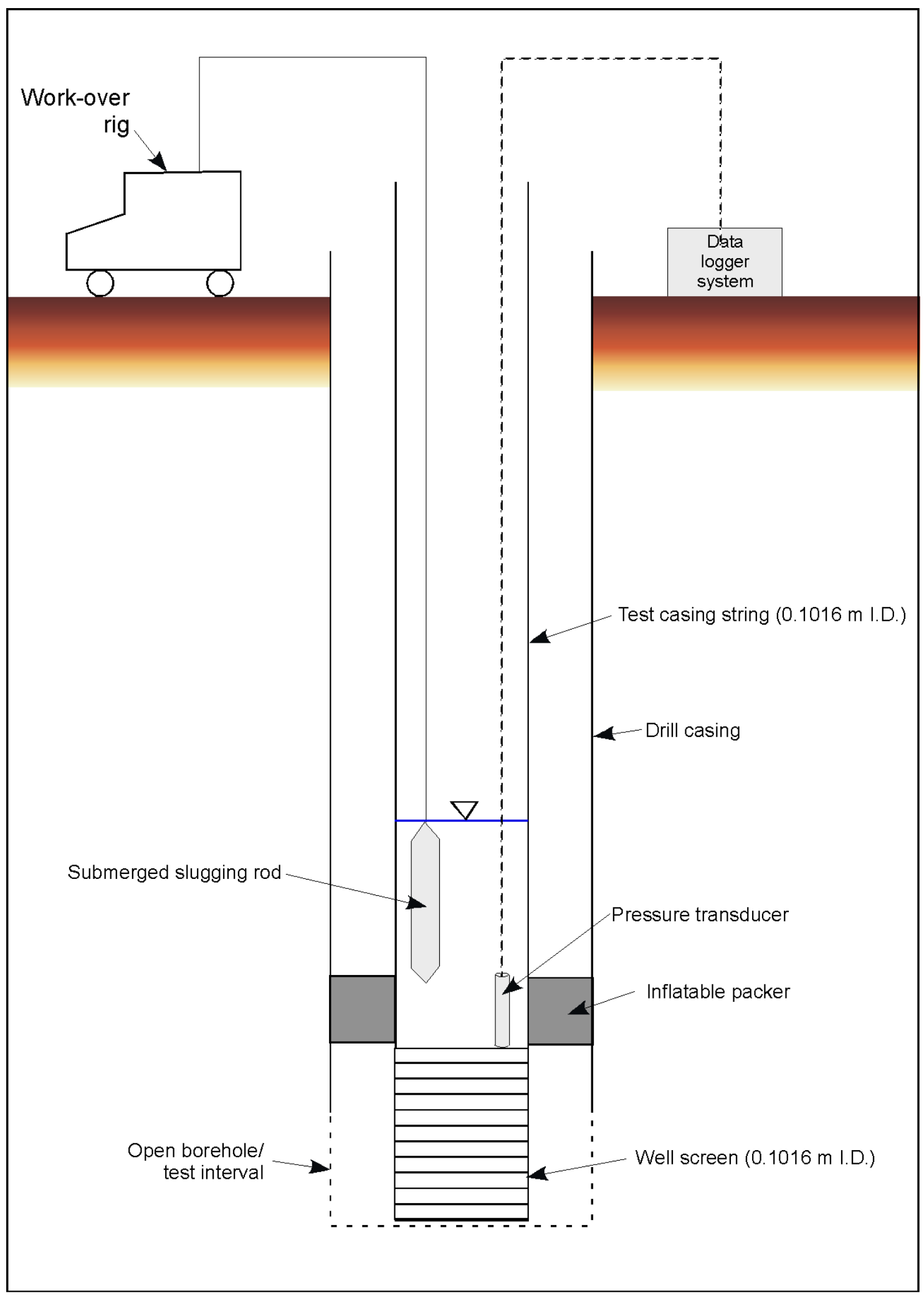

Figure 2.1. General Slug Test Configuration Using Slugging Rods 


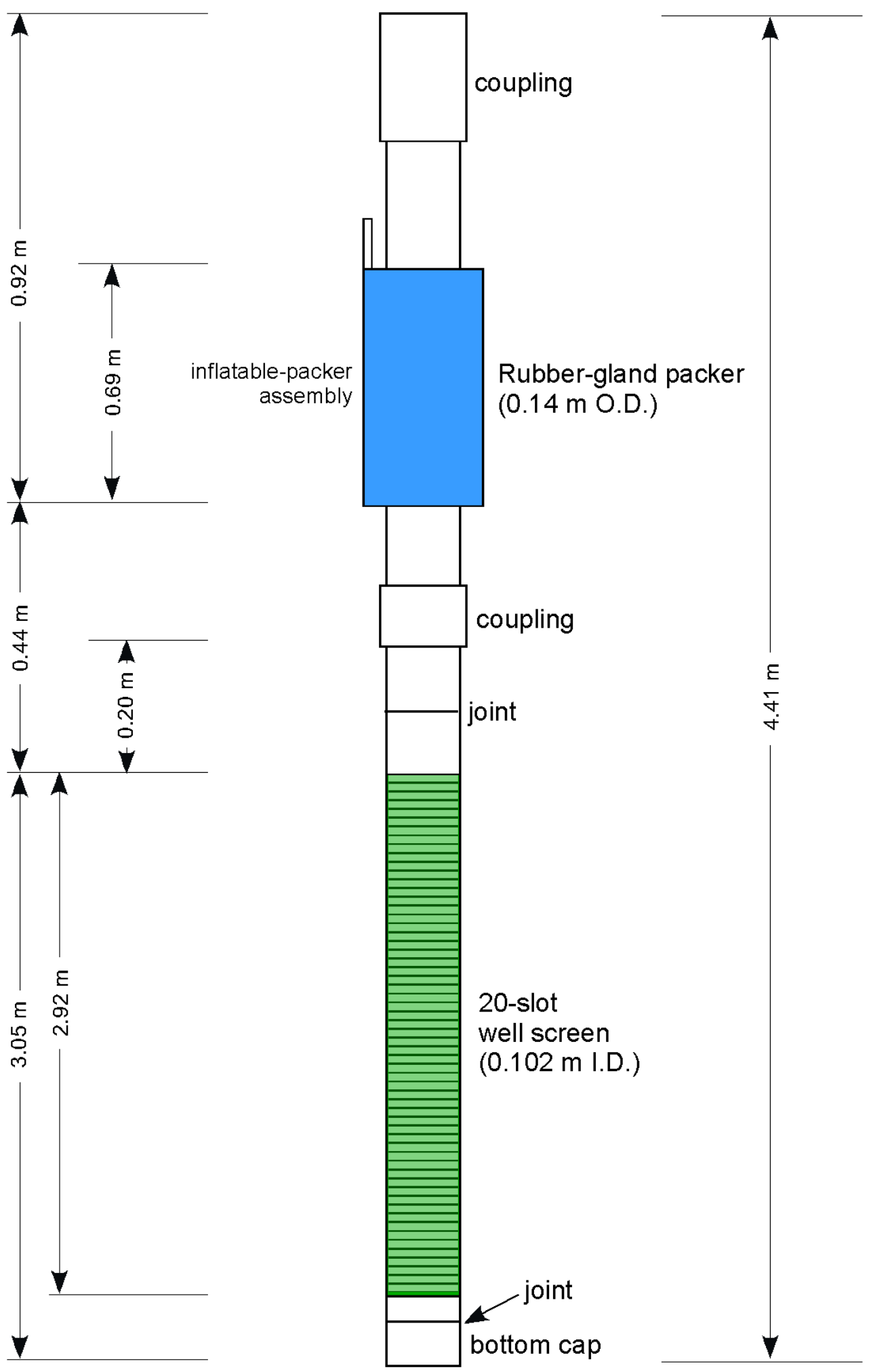

Figure 2.2. Packer/Well-Screen Assembly Dimensions 


\subsection{Slug Test Response/Analysis}

The following discussion pertaining to slug-test response and analysis is taken primarily from Spane (see Footnote [a], p. 1.1). As shown in Figure 3.1 and discussed in Butler (1998) and Spane et al. (2003b), water levels within a test well can respond in one of three ways to the instantaneously applied stress of a slug test. These response model patterns are 1) an over-damped response, where the water levels recover in an exponentially decreasing recovery pattern, 2) an under-damped response, where the slug-test response oscillates above and below the initial static, with decreasing peak amplitudes with time, and 3) a critically damped response, where the slug test behavior exhibits characteristics that are transitional to the over- and under-damped response patterns. Factors that control the type of slug-test response model that will be exhibited within a well include a number of aquifer properties (hydraulic conductivity) and welldimension characteristics (well-screen length, well-casing radius, well-radius, aquifer thickness, fluidcolumn length) and can be expressed by the response-damping parameter, $\mathrm{C}_{\mathrm{D}}$, which Butler (1998) reports for unconfined aquifer tests as:

$$
\mathrm{C}_{\mathrm{D}}=\left(\mathrm{g} / \mathrm{L}_{\mathrm{e}}\right)^{1 / 2} \mathrm{r}_{\mathrm{c}}^{2} \ln \left(\mathrm{R}_{\mathrm{e}} / \mathrm{r}_{\mathrm{w}}\right) /(2 \mathrm{~K} \mathrm{~L})
$$

where $\mathrm{g}=$ acceleration due to gravity

$\mathrm{L}_{\mathrm{e}}=$ effective well water-column length

$\mathrm{r}_{\mathrm{C}}=$ well casing radius; i.e., radius of well water-column that is active during testing

$\mathrm{R}_{\mathrm{e}}=$ effective test radius parameter; as defined by Bouwer and Rice (1976)

$\mathrm{r}_{\mathrm{w}}=$ well radius

$\mathrm{K}=$ hydraulic conductivity of test interval

L well-screen length.

Given the multitude of possible combinations of aquifer properties, well-casing dimensions, and testinterval lengths, no universal $C_{D}$ value ranges can be provided that describe slug-test response conditions. However, for various combinations anticipated for testing at ZP-1 well sites during drilling, the following general guidelines on predicting slug-test responses are provided:

- $\mathrm{C}_{\mathrm{D}}>3=$ over-damped response

- $\mathrm{C}_{\mathrm{D}} 1-3=$ critically damped response

- $\mathrm{C}_{\mathrm{D}}<1=$ under-damped response. 


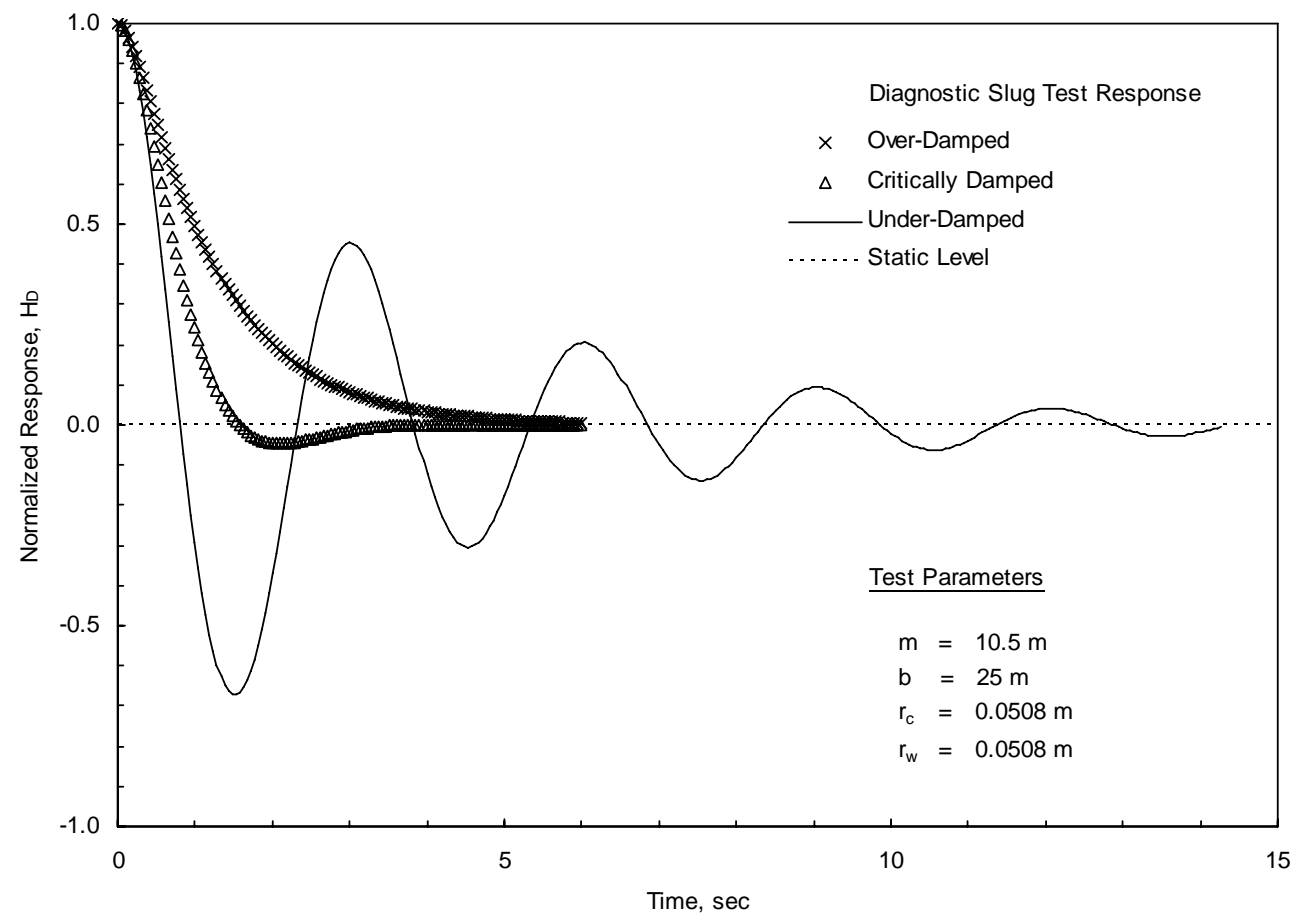

Figure 3.1. Diagnostic Slug Test Response (taken from Spane et al. (2003a)

An over-damped test response generally occurs within stress wells monitoring test formations of low to moderately high hydraulic conductivity (e.g., Ringold Formation) and are indicative of test conditions where frictional forces (i.e., resistance of groundwater flow from the test interval to the well) are predominant over test-system inertial forces. All ZP-1 well test intervals exhibited over-damped response characteristics. Figure 3.2 shows predicted slug-test recovery as a function of hydraulic conductivity (K range: 2.5 to $40 \mathrm{~m} /$ day; $1.5-\mathrm{m}$ test interval) for test intervals exhibiting over-damped response characteristics and for general ZP-1 test well/interval conditions. The test predictions shown in the figure are based on responses occurring within a test system casing I.D. $=0.1016 \mathrm{~m}$. As indicated in the figure, test intervals having hydraulic conductivity values of approximately $40 \mathrm{~m} /$ day or less should be readily resolved for tests exhibiting over-damped slug-test behavior. For over-damped slug tests, two different methods can be used for the slug-test analysis: the semiempirical, straight-line analysis method described in Bouwer and Rice (1976) and Bouwer (1989) and the type-curve-matching method for unconfined aquifers presented in Butler (1998). For over-damped slug tests, hydraulic-conductivity estimates obtained using the Bouwer and Rice analytical method are generally less reliable than corresponding estimates obtained using the type-curve-matching method (Hyder and Butler 1995; Butler 1998). For this reason, only the type-curve-matching analytical method was used for estimating hydraulic conductivity for zones tested at the ZP-1 wells. A detailed description of over-damped, slug-test-analysis methods is presented in Spane and Newcomer (2004). 


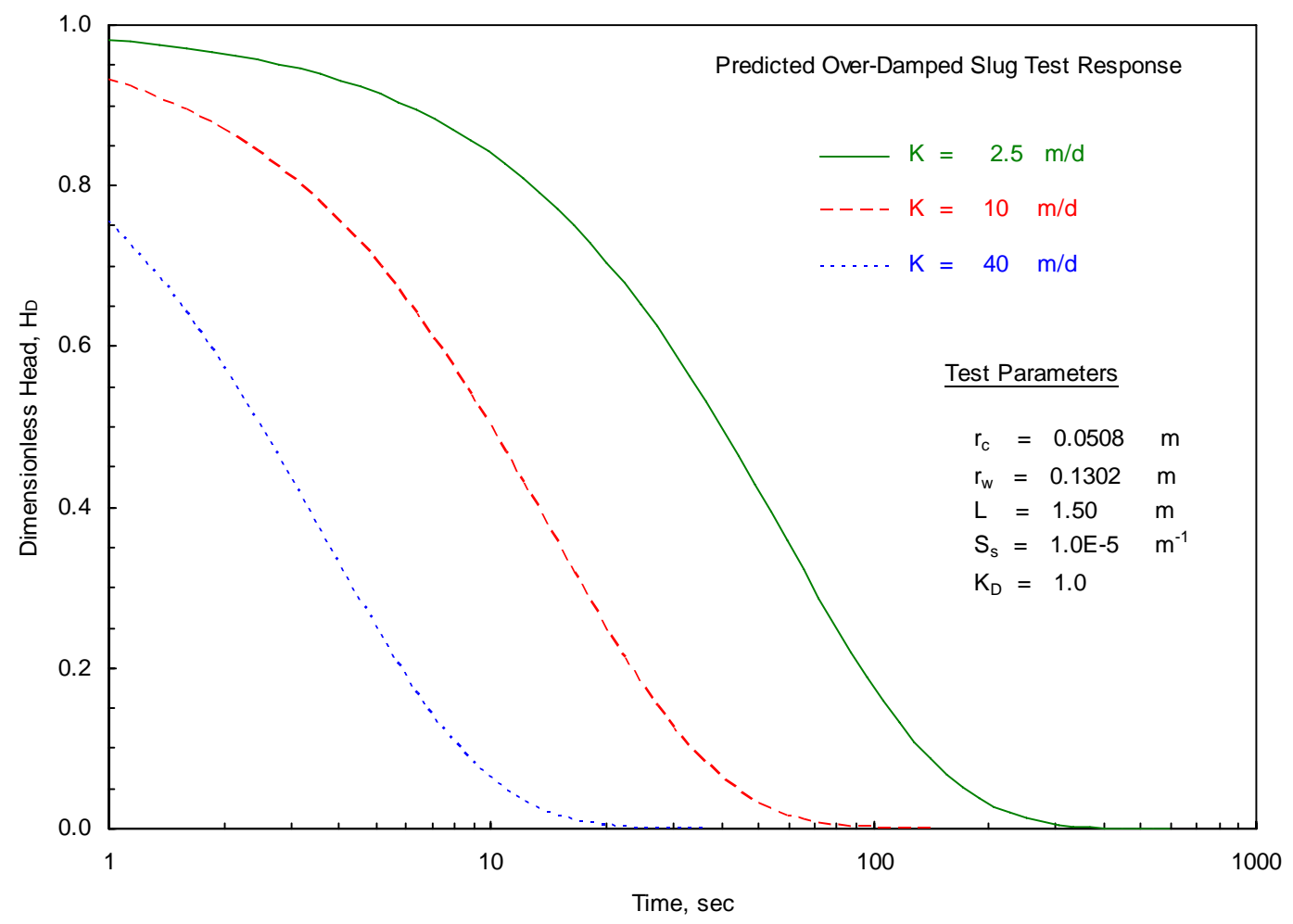

Figure 3.2. Over-Damped Slug-Test Response as a Function of Test-Interval Hydraulic Conductivity

Under-damped test-response patterns are exhibited within stress wells where inertial forces are predominant over formation frictional forces. This commonly occurs in wells with extremely long fluid columns (i.e., large water mass within the well column) and/or that penetrate highly permeable aquifers (e.g., Hanford formation). Tests exhibiting under-damped behavior should be conducted with very small stress-level applications. No ZP-1 well test intervals displayed formational test-response characteristics that were under damped.

As mentioned previously, critically damped test responses are indicated by stress well water-level responses that are transitional to the over- and under-damped test conditions, as shown in Figure 3.1. They typically occur in wells that monitor test formations exhibiting intermediate to high hydraulic conductivity. As noted in Butler (1998), distinguishing between slug-test responses that are over damped and critically damped may be difficult in some cases (i.e., due to test signal noise) when examined on arithmetic plots. Proper model identification may be enhanced when semi-log plots are used, i.e., log head versus time (e.g., Bouwer and Rice plot). Critically damped slug tests exhibit a diagnostic concavedownward pattern when plotted in this semi-log plot format. This is in contrast to over-damped response behavior, which displays either a linear or concave upward (elastic) pattern. Critically damped slug-test responses are influenced by processes (e.g., inertial) that are not accounted for in the previously discussed slug-test analytical methods (i.e., for over-damped tests). Because of this, slug tests exhibiting these response characteristics cannot be analyzed quantitatively using the Bouwer and Rice or standard typecurve methods. High-K analysis methods that can be employed for analyzing unconfined aquifer tests exhibiting response behavior that is either critically damped or under damped include those described in 
Springer and Gelhar (1991), Butler (1998), McElwee and Zenner (1998), McElwee (2001), Butler and Garnett (2000), and Zurbuchen et al. (2002). Because of the ease provided by a spreadsheet-based approach, the test-analysis method presented in Butler and Garnett (2000) is preferred for analyzing tests exhibiting critically damped behavior. A detailed discussion of this analytical procedure and method is presented in Spane and Newcomer (2004). No ZP-1 well test intervals displayed formational testresponse characteristics that were critically damped. 


\subsection{Slug-Test Results}

The following discussion presents pertinent information describing slug testing activities and analysis results for the test/depth zones that were hydrologically characterized at the ZP-1 boreholes as they were advanced to their final drilling depths. Table 4.1 presents pertinent slug-test information for the respective test/depth intervals while Table 4.2 summarizes the slug-test-analysis results. Selected borehole logs are presented in Appendix B, which can be referred to for a geologic description of the respective well test zone/depth intervals.

Table 4.1. Slug-Test Characteristics for Selected Test/Depth Intervals at Operable Unit ZP-1 Test Wells 299-W10-33 and 299-W11-48

\begin{tabular}{|c|c|c|c|c|c|c|c|}
\hline \multirow[b]{2}{*}{ Test Well } & \multirow[b]{2}{*}{$\begin{array}{l}\text { Test } \\
\text { Zone }\end{array}$} & \multicolumn{4}{|c|}{ Test Parameters } & \multirow{2}{*}{$\begin{array}{c}\text { Diagnostic Slug } \\
\text { Test Response } \\
\text { Model }\end{array}$} & \multirow[b]{2}{*}{$\begin{array}{l}\text { Hydrogeologic } \\
\text { Unit Tested }^{(a)}\end{array}$} \\
\hline & & Test Date & $\begin{array}{c}\text { Number } \\
\text { of Slug } \\
\text { Tests }\end{array}$ & $\begin{array}{l}\text { Depth to } \\
\text { Water, } \\
\text { m bgs }\end{array}$ & $\begin{array}{c}\text { Depth/Test } \\
\text { Interval, } \\
\text { m bgs }\end{array}$ & & \\
\hline 299-W10-33 & Zone 1 & 7/6/07 & 5 & 69.98 & $\begin{array}{c}73.2-74.2 \\
(1.0)\end{array}$ & $\begin{array}{c}\text { Homogeneous } \\
\text { Formation/ } \\
\text { Exponential-Decay } \\
\text { (over-damped) }\end{array}$ & $\begin{array}{l}\text { Ringold } \\
\text { Formation } \\
\text { (Unit 5) }\end{array}$ \\
\hline \multirow[b]{2}{*}{ 299-W11-48 } & Zone 1 & $4 / 6 / 07$ & $6^{(\mathrm{b})}$ & 73.64 & $\begin{array}{c}76.8-78.4 \\
(1.6)\end{array}$ & $\begin{array}{c}\text { Heterogeneous } \\
\text { Formation/ } \\
\text { Exponential Decay } \\
\text { (over-damped) }\end{array}$ & $\begin{array}{l}\text { Ringold } \\
\text { Formation } \\
\text { (Unit 5) }\end{array}$ \\
\hline & Zone 2 & 4/12/07 & $4^{(\mathrm{b})}$ & 73.79 & $\begin{array}{c}82.8-84.3 \\
(1.5)\end{array}$ & $\begin{array}{c}\text { Heterogeneous } \\
\text { Formation/ } \\
\text { Exponential Decay } \\
\text { (over-damped) }\end{array}$ & $\begin{array}{l}\text { Ringold } \\
\text { Formation } \\
\text { (Unit 5) }\end{array}$ \\
\hline \multicolumn{8}{|c|}{$\begin{array}{l}\text { (a) Assumed to be uniform within the well-screen test section. } \\
\text { Note: For all test wells, } \mathrm{r}_{\mathrm{c}}=0.0508 \text { meter; } \mathrm{r}_{\mathrm{w}} \text { ranged between } 0.1302 \text { and } 0.1365 \text { meters. } \\
\text { Unit number in parentheses indicates the relevant groundwater-flow model layer, as described in Thorne, et al. } \\
\text { 1993. } \\
\text { (b) Only two of the slug tests provided analyzable results. }\end{array}$} \\
\hline
\end{tabular}


Table 4.2. Slug-Test-Analysis Results

\begin{tabular}{|c|c|c|c|}
\hline \multirow[b]{2}{*}{ Test Well } & \multirow[b]{2}{*}{$\begin{array}{l}\text { Test } \\
\text { Zone }\end{array}$} & \multicolumn{2}{|c|}{$\begin{array}{c}\text { Type-Curve Analysis } \\
\text { Method }\end{array}$} \\
\hline & & $\begin{array}{l}\text { Horizontal } \\
\text { Hydraulic } \\
\text { Conductivity, } \\
\mathbf{K}_{\mathrm{h}}{ }^{(a)}(\mathbf{m} / \text { day) }\end{array}$ & $\begin{array}{c}\text { Specific } \\
\text { Storage, } \\
\mathrm{S}_{\mathrm{s}}\left(\mathrm{m}^{-1}\right) \\
\end{array}$ \\
\hline 299-W10-33 & Zone 1 & $\begin{array}{c}13.0-17.3 \\
(15.7)\end{array}$ & $1.0 \mathrm{E}-5$ \\
\hline \multirow{2}{*}{ 299-W11-48 } & Zone 1 & $\begin{array}{c}1.17-1.30 \\
(1.24)\end{array}$ & $5.0 \mathrm{E}-5-1.0 \mathrm{E}-4$ \\
\hline & Zone 2 & $\begin{array}{c}5.62-6.91 \\
(6.27)\end{array}$ & $1.0 \mathrm{E}-5$ \\
\hline \multicolumn{4}{|c|}{$\begin{array}{l}\text { Number in parentheses is the average value for all tests. } \\
\text { (a) Assumed to be uniform within the well-screen test } \\
\text { section. }\end{array}$} \\
\hline
\end{tabular}

\subsection{Well 299-W11-48 (C5243)}

The drilling of OU ZP-1 well 299-W11-48 was initiated on November 29, 2006, and continued until reaching a final depth of 124.7-m bgs on June 4, 2007. The Lower Mud unit of the Ringold Formation was not encountered during drilling, which represents the bottom boundary of the unconfined aquifer at this location. Based on projections from neighboring well sites, however, the Lower Mud unit contact would be expected at a depth of 130 to 140 -m bgs. Two test-depth intervals were tested at the borehole location: Zone $1=76.8$ to $78.4 \mathrm{~m}$ bgs; and Zone $2=82.8$ to $84.3 \mathrm{~m}$ bgs.

\subsubsection{Zone 1}

After reaching a depth of 78.4-m bgs, the packer/well-screen assembly was lowered to the bottom of the borehole and the $0.2731-\mathrm{m}$ O.D. $\left(10-{ }^{3} / 4\right.$ inch O.D.) dual-wall, and the drill casing retracted $1.6 \mathrm{~m}$, producing a test/depth interval for Zone 1 of 76.8 to 78.4-m bgs. The borehole geology log (Appendix B; Figure B.1) indicates that the test-interval section generally consists of a silty sandy gravel unit, composed of 60 to $70 \%$ gravel, 30 to $35 \%$ sand, and 10 to $20 \%$ silt.

A series of three slug injection tests (two low and one high stress test) and a series of three slug withdrawal (two low and one high stress test) were conducted between 1349 hours and 1609 hours (PST), April 6, 2007. The low-stress slug-injection and withdrawal tests were unsuccessful and yielded test data that could not be analyzed. The high-stress slug injection (SI \#3) and withdrawal (SW \#3) tests were marginally successful using a slugging rod with a volume of $0.011 \mathrm{~m}^{3}$. This slug-rod volume imparted a theoretical applied stress value of $1.36 \mathrm{~m}$ for the high-stress tests. Downhole test-interval response pressures during testing were monitored using a 0 to $20 \mathrm{psig}$ ( 0 to $138 \mathrm{kPa}$ ) pressure transducer set at a depth of $~ 76.7-\mathrm{m}$ bgs. The static depth-to-water for the test interval during testing was 73.64-m bgs.

A diagnostic analysis of slug tests conducted for this test/depth interval indicates a heterogeneous formation/composite response condition. This composite pattern exhibits a high-permeability, fast-initial- 
recovery, inner-zone response, which transitions to a lower permeability response for the surrounding outer-zone formation. The presence of a high-permeability inner-zone is believed to be reflective of an artificially created condition. This artificially created high-permeability condition may be attributed to the setting of a smaller diameter packer/well-screen assembly and the retraction of the much larger diameter drill casing to expose the test/depth interval. The creation of an artificial high-permeability inner-zone (surrounding the temporary well screen) is believed to be the result of dislodged gravel and cobbles collapsing around the temporary well screen as the drill casing was retracted. An examination of the drilling log geologic description indicates the presence of a high percentage of silty, sandy gravel for this particular test/depth interval.

As discussed in Spane (see Footnote [a], p. 1.1), slug tests exhibiting linear response characteristics for heterogeneous formation tests can be analyzed quantitatively using the homogeneous-formation-analysis approaches described in Section 4. For the homogeneous-formation analysis, the type-curve method estimates for $\mathrm{K}$ ranged between 1.17 and $1.30 \mathrm{~m}$ /day (average $1.24 \mathrm{~m} /$ day) for the various high-stresslevel tests for the formational outer-zone. Selected examples of the diagnostic and test analysis plots for this test/depth interval are shown in Figure 4.1a and b, respectively.

\subsubsection{Zone 2}

After reaching a depth of 84.3-m bgs, the packer/well-screen assembly was lowered to the bottom of the borehole, and the 0.2731 -m O.D. (10- ${ }^{3} / 4$-inch O.D.) dual-wall, drill casing retracted $1.5 \mathrm{~m}$, producing a test/depth interval for Zone 2 of 82.8 to 84.3 -m bgs. The borehole geology log (Appendix B; Figure B.1) indicates that the test interval section generally consists of a silty sandy gravel unit similar to Zone 1 , composed of 60 to $70 \%$ gravel, 30 to $35 \%$ sand, and 10 to $20 \%$ silt.

A series of four slug withdrawal tests (all low stress tests) were conducted between 1029 hours and 1130 hours (PST), April 12, 2007. High-stress tests could not be performed because the larger slugging rod (i.e., volume of $0.011 \mathrm{~m}^{3}$ ) would not go past the first pipe joint near the surface. Only two of the four low-stress slug tests (i.e., SW \#1 and SW \#3) were performed successfully, but yielded noisy data, using a slugging rod with a volume of $0.006 \mathrm{~m}^{3}$. This slug-rod volume imparted a theoretical applied stress value of $0.68 \mathrm{~m}$ for the low-stress tests. It is not known what contributed to the noise in the data, but it is suspected to be vibrations associated with the drill-rig engine used to power the raising of the slugging rod. Downhole test-interval response pressures during testing were monitored using a 0 to 5 psig ( 0 to $35 \mathrm{kPa}$ ) pressure transducer set at a depth of $\sim 76.6$-m bgs. The static depth-to-water for the test interval during testing was 73.79-m bgs.

As for tests conducted for overlying Zone 1, a diagnostic analysis of slug tests conducted for this test/depth interval indicates a heterogeneous-formation/composite-response condition. This composite pattern exhibits a high permeability, fast initial recovery, and inner-zone response, which transitions to a lower permeability surrounding the outer-zone-formation response. The presence of a high permeability inner-zone is believed to be reflective of an artificially created condition. This artificially created high permeability condition may be attributed to the setting of a smaller diameter packer/well-screen assembly and retraction of the much larger diameter drill casing to expose the test/depth interval. The creation of an artificial high-permeability inner-zone (surrounding the temporary well screen) is believed to be the result of dislodged gravel and cobbles collapsing around the temporary well screen while the drill casing 
(a)

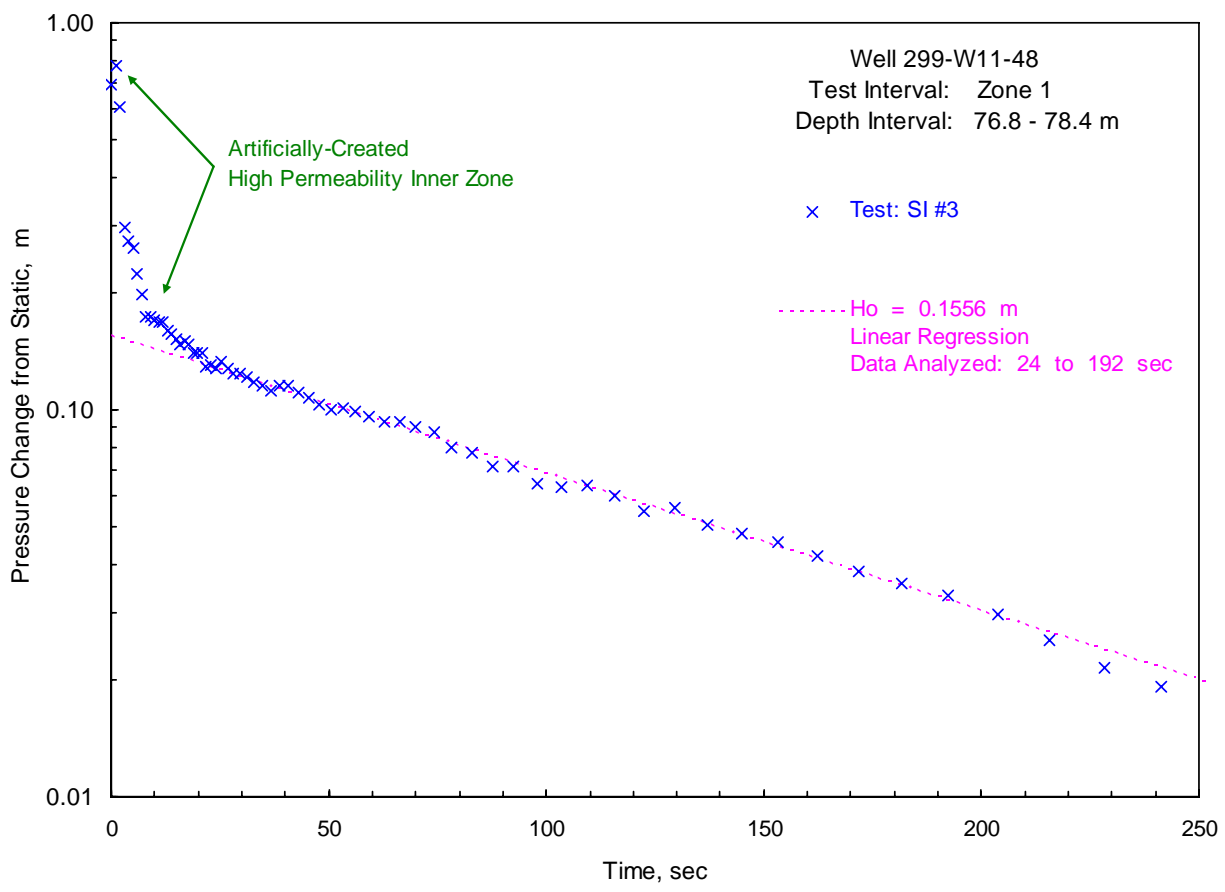

(b)

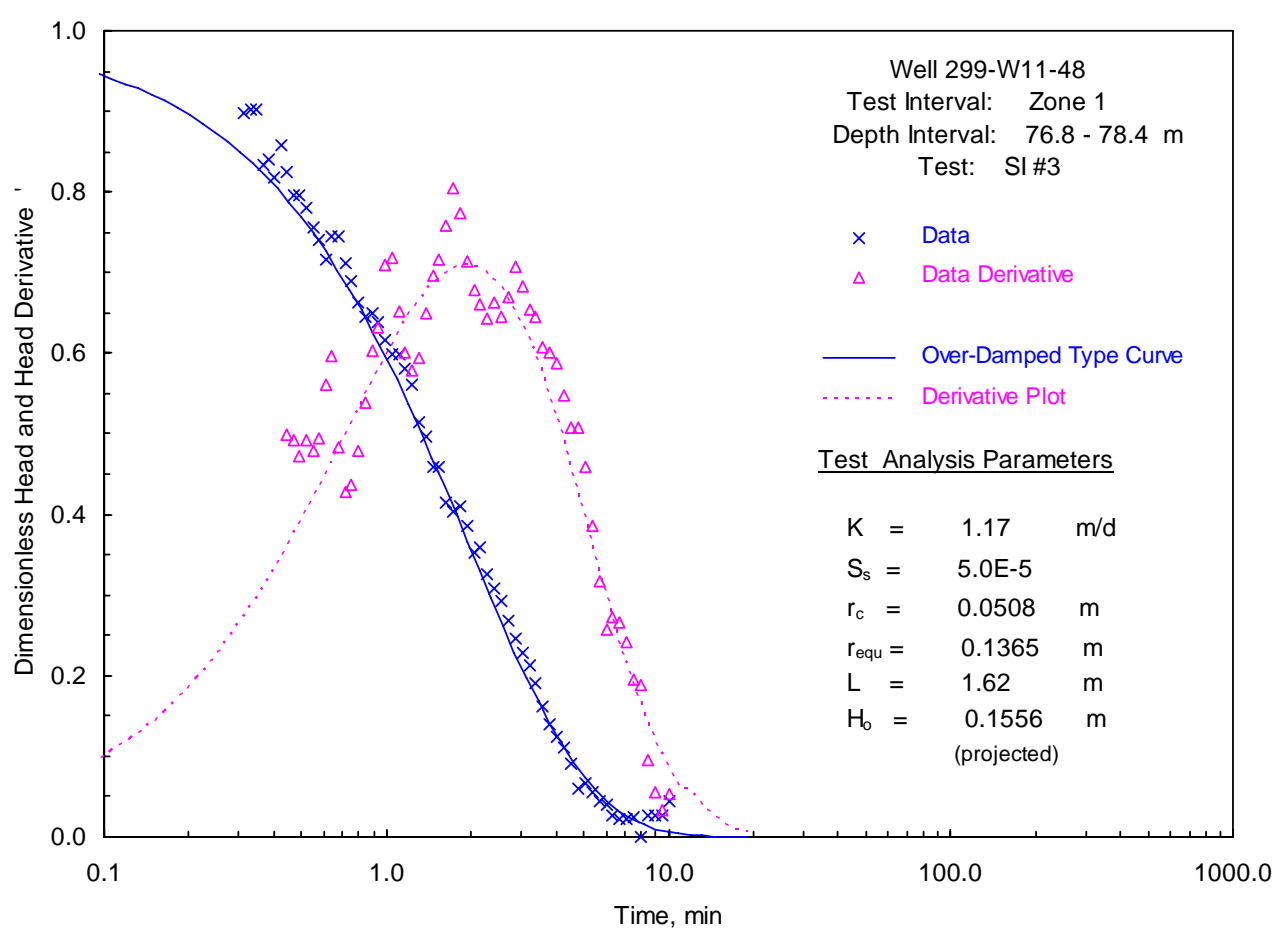

Figure 4.1. Selected Slug Test Analysis Plot for Well 299-W11-48: (a) Diagnostic(top) and (b) TypeCurve Analysis Method (bottom) 
is being retracted. An examination of the drilling-log geologic description indicates the presence of a high percentage of silty, sandy gravel for this particular test/depth interval.

As discussed in Spane (see Footnote [a], p. 1.1), slug tests exhibiting linear, heterogeneous-formation, test-response characteristics can be analyzed quantitatively using the homogeneous-formation-analysis approaches described in Section 4. For the homogeneous-formation analysis, the type-curve method estimates for $\mathrm{K}$ ranged between 5.62 and $6.91 \mathrm{~m} /$ day (average $6.27 \mathrm{~m} /$ day) for the various low-stress-level tests for the formational outer-zone. It should be noted that the K estimates for this test interval have a higher degree of uncertainty, due to the high dissipation of low-stress slug tests by the artificially created, higher permeability, inner zone. Selected examples of the diagnostic and test analysis plots for this test/depth interval are shown in Figure 4.2a and b, respectively.

\subsection{Well 299-W10-33 (C5855)}

During drilling of OU ZP-1 well 299-W10-33, the Lower Mud unit of the Ringold Formation was not encountered, which represents the bottom boundary of the unconfined aquifer at this location. Based on projections from neighboring well sites, however, the Lower Mud unit contact would be expected at a depth of 130 to 140 -m bgs. One test-depth interval was tested at the borehole location; Zone $1=73.2-$ to 74.2-m bgs.

\subsubsection{Zone 1}

After reaching a depth of 74.9-m bgs, the packer/well-screen assembly was lowered to a depth of 74.2-m bgs, and the 0.2604-m O.D. (10- $1 / 4$ inch O.D.) dual-wall drill casing retracted $1.0 \mathrm{~m}$, producing a test/depth interval for Zone 1 of 73.2- to 74.2-m bgs. The borehole geology log for well 299-W10-33 was not available for this report.

A series of five slug withdrawal tests (two low-stress and three high-stress tests) were conducted between 1203 hours and 1444 hours (PST), July 6, 2007. The slug tests were initiated using slugging rods having two different displacement volumes. The calculated slugging-rod volumes impart theoretical applied stress values of 0.68 and $1.16 \mathrm{~m}$ for the low and high stress tests, respectively. Downhole test-interval response pressures during testing were monitored using a 0 to 5 psig ( 0 to $35 \mathrm{kPa}$ ) pressure transducer set at a depth of $\sim 72.5$-m bgs. The static depth-to-water for the test interval during testing was 69.98-m bgs.

The low-stress, slug-test responses indicate a linear, inelastic (storage), over-damped, slug-test behavior (e.g. Figure 4.3). The low-stress slug tests exhibited homogeneous-formation conditions over the entire test response. For the high-stress slug tests, a comparison of the normalized slug-test responses indicates a linear, inelastic (storage), over-damped, slug-test behavior during the early part of the test. There is some indication that test responses yield to a slightly critically damped condition during the latter part of the tests, as shown by the slightly curvi-linear semi-log plot (Figure 4.4). A comparison between normalized low and high stress tests indicates slight differences in response behavior, suggesting that the well had not been developed sufficiently to establish stable skin conditions. 
(a)

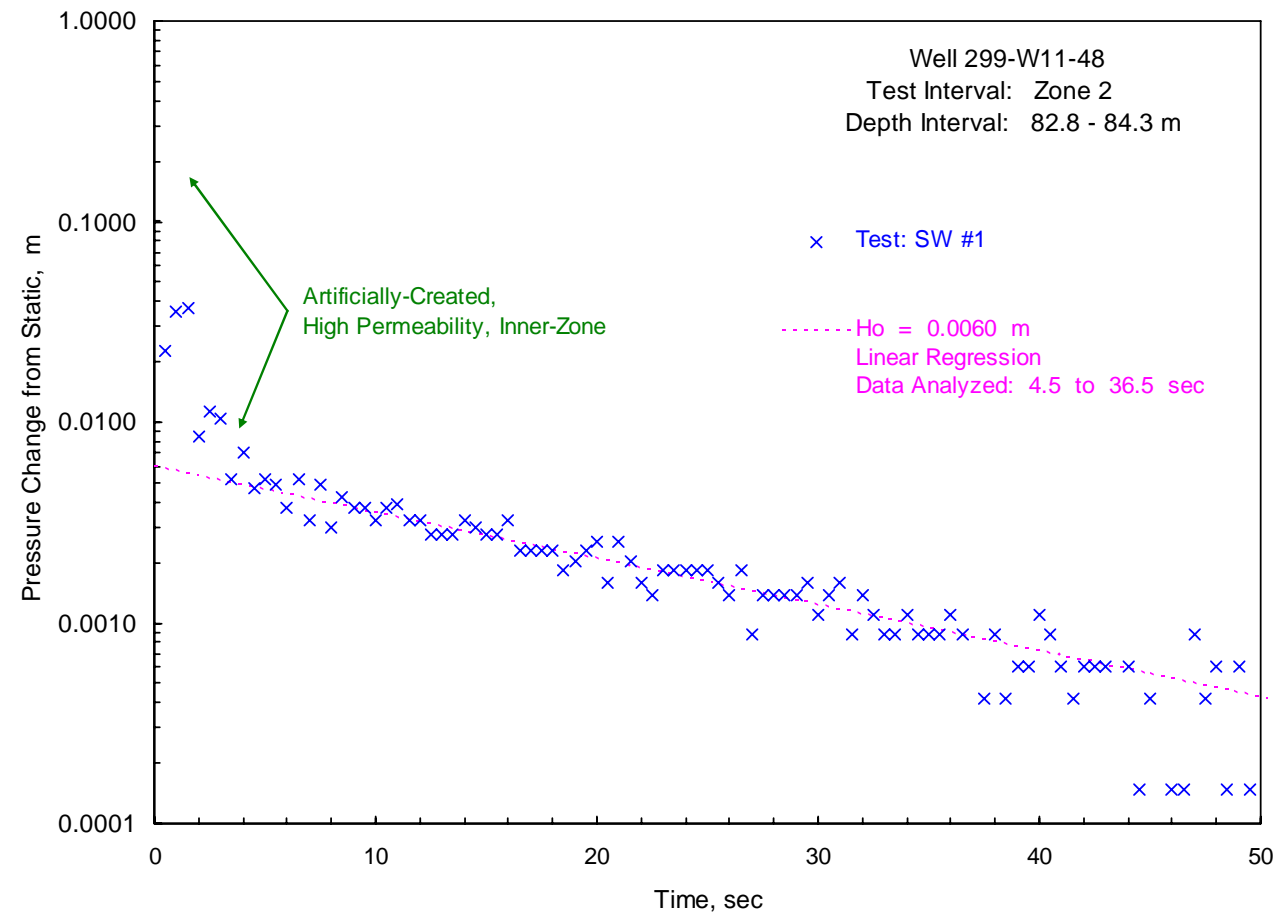

(b)

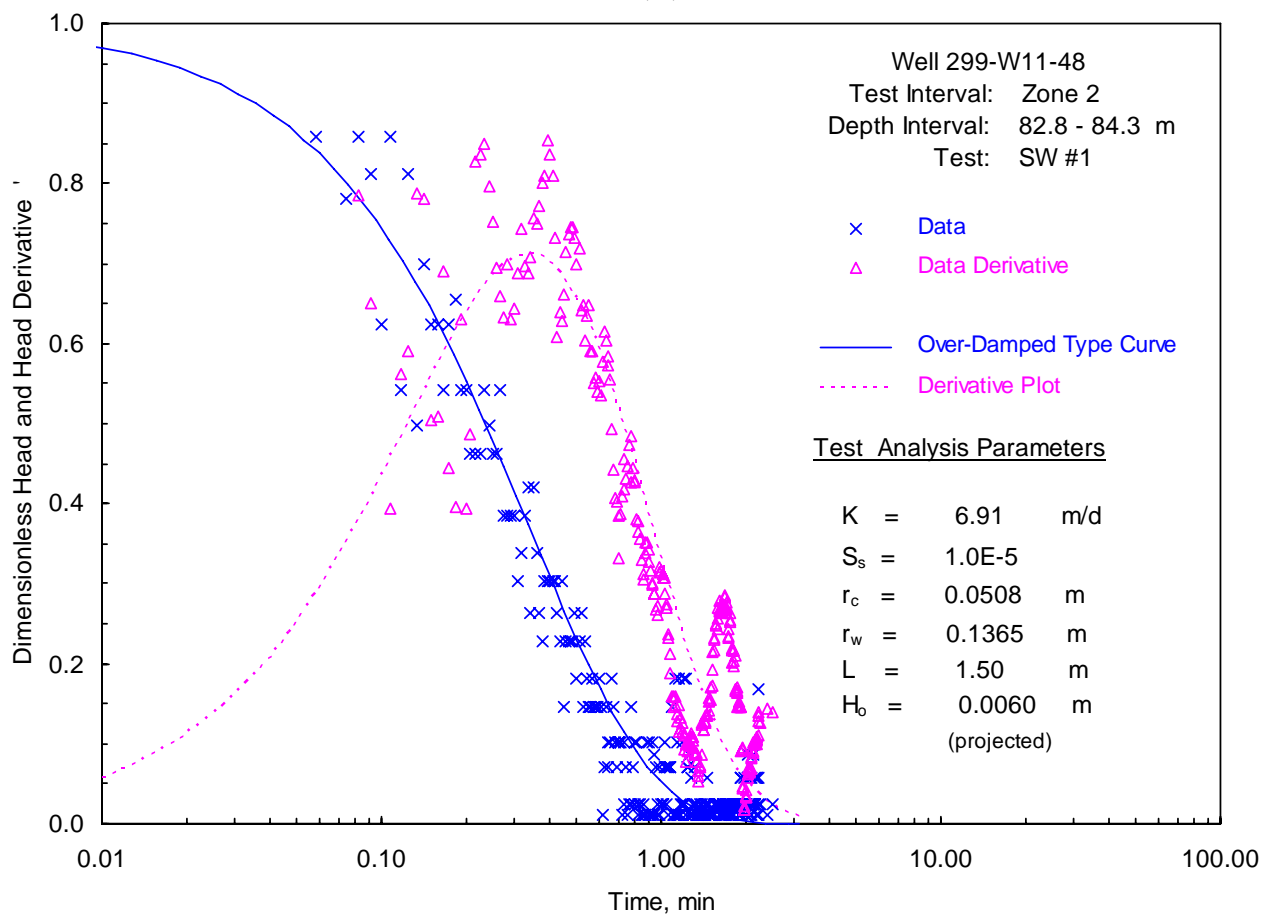

Figure 4.2. Selected Slug-Test-Analysis Plot for Well 299-W11-48: (a) Diagnostic (top) and (b) TypeCurve Analysis Method (bottom) 
Slug-test results exhibiting homogeneous-formation response behavior can be analyzed quantitatively using standard, linear-response-based analytical methods (i.e., using standard type-curve methods) following procedures described in Spane and Newcomer (2004). Estimates for K using the type-curve method ranged between 13.0 and $17.3 \mathrm{~m} /$ day, with an average of $15.7 \mathrm{~m} /$ day for the five slug-withdrawal tests. Figure 4.3 shows a selected example of the analysis plots for this test interval.

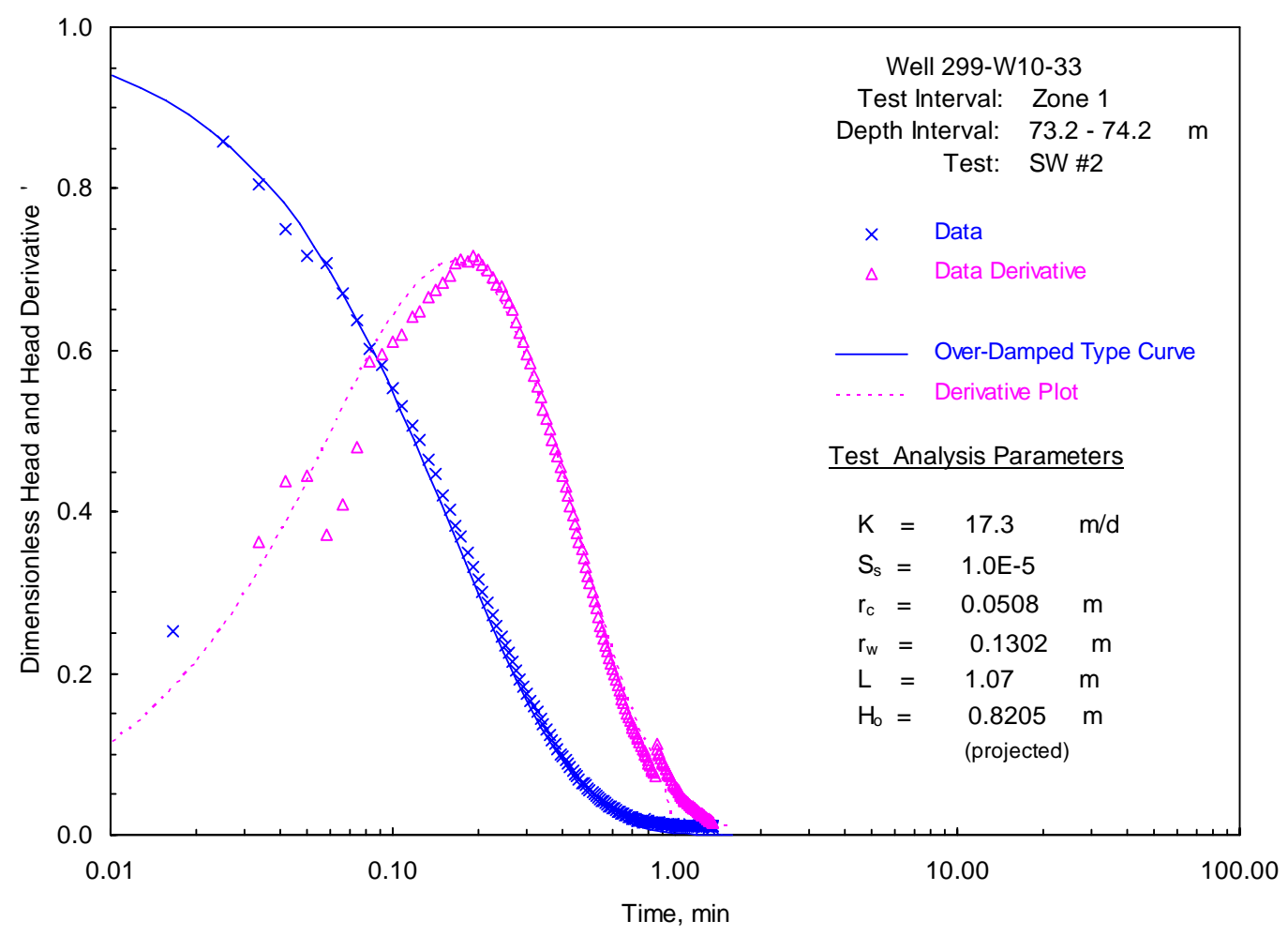

Figure 4.3. Selected Slug Test Analysis Plot for Well 299-W10-33: Test Interval Zone 1 (Type-Curve Method) 


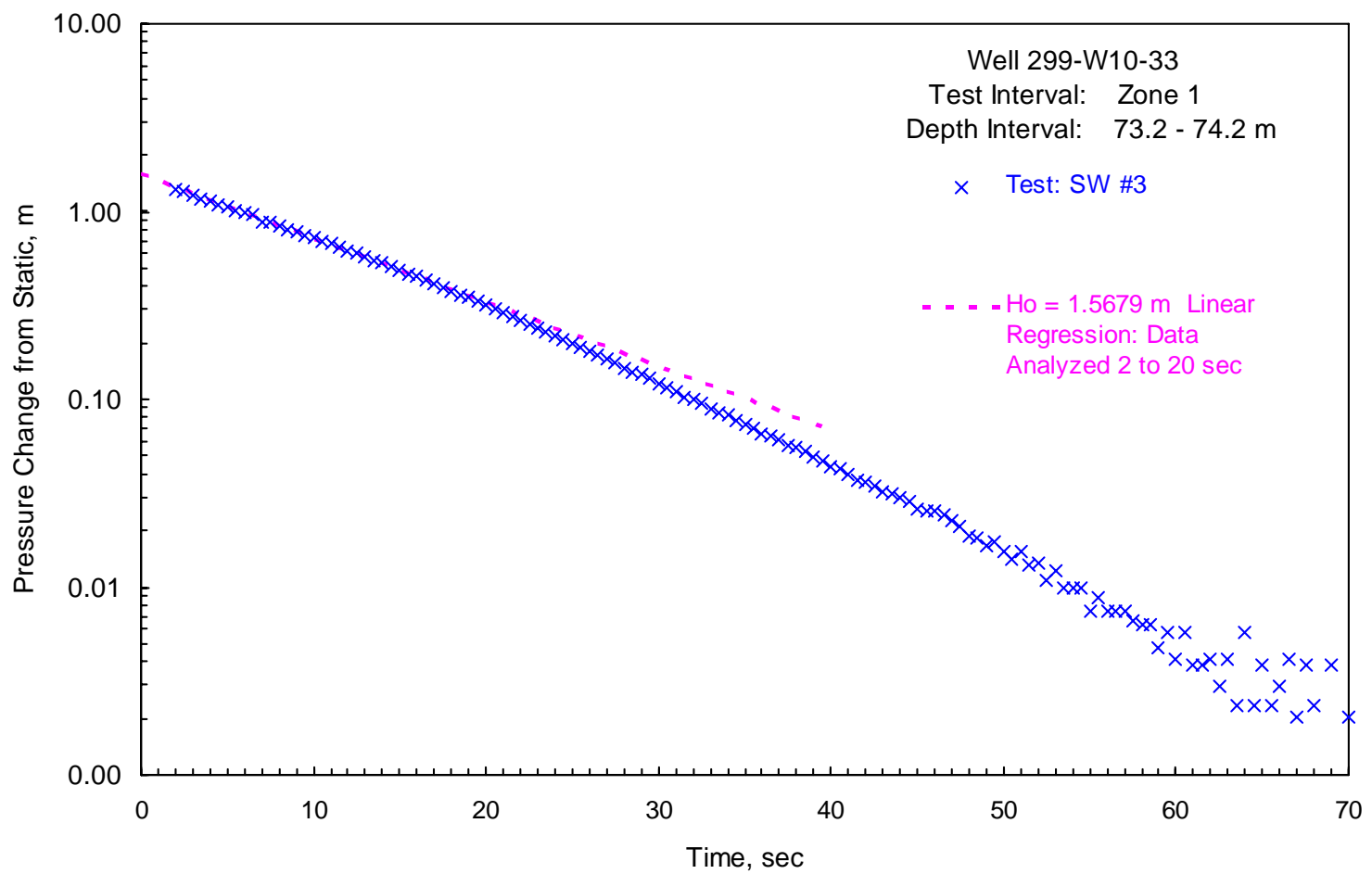

Figure 4.4. A High-Stress Slug Test Showing Slightly Critically Damped Behavior on a Semi-Log Plot for Test Interval Zone 1, Well 299-W10-33 


\subsection{Conclusions}

Slug-test results were obtained for a total of three test/depth intervals during the drilling and borehole advancement of two OU ZP-1 wells: 299-W10-33 and 299-W11-48. The results indicate that multiple, stress-level, slug-testing methods were successful at well 299-W10-33 in providing detailed hydraulic conductivity information for two test zones. For well 299-W11-48, the slug-test results were marginally successful, and only one stress-level test for each of the two zones tested was achieved.

Results from the ZP-1 well slug tests provide hydraulic-characterization information only for the Ringold Formation (Unit 5) for individual test/depth intervals generally sited within the upper $10 \mathrm{~m}$ of the unconfined aquifer. All test/depth intervals exhibit exponential-decay (over-damped) slug-test response behavior. However, the high-stress slug tests performed at well 299-W10-33 indicate slightly critically damped response behavior during the latter part the tests. Over-damped, slug-test response patterns are indicative of test intervals having low to intermediate permeability conditions, while critically damped test responses are reflective of test intervals having intermediate to high-permeability characteristics. An analysis of the slug-test results indicates calculated average test-interval estimates of hydraulic conductivities ranging between 1.24 and $15.7 \mathrm{~m}$ /day (Table 4.2). The ZP-1 well hydraulic-conductivity estimates were derived for test-interval sections that ranged from 1.0 to $1.6 \mathrm{~m}$ in length (Table 4.1). 


\subsection{References}

Bouwer H. 1989. “The Bouwer and Rice slug test - an update.” Ground Water 27(3):304-309.

Bouwer H, and RC Rice. 1976. "A slug test for determining hydraulic conductivity of unconfined aquifers with completely or partially penetrating wells.” Water Resources Research 12(3):423-428.

Butler JJ, Jr. 1998. The design, performance, and analysis of slug tests. Lewis Publishers, CRC Press, Boca Raton, Florida.

Butler JJ, Jr, and EJ Garnett. 2000. Simple procedures for analysis of slug tests in formations of high hydraulic conductivity using spreadsheet and Scientific Graphics Software. Open-file Report 2000-40, Kansas Geological Survey, Lawrence, Kansas.

Hyder Z, and JJ Butler, Jr. 1995. "Slug tests in unconfined formations: An assessment of the Bouwer and Rice technique.” Ground Water 33(1):16-22.

McElwee CD, and MA Zenner. 1998. “A nonlinear model for analysis of slug-test data.” Water Resources Research 34(1):55-66.

McElwee CD. 2001. “Application of a nonlinear slug test model.” Ground Water 39(5):737-744.

Spane FA, Jr, and DR Newcomer. 2004. Results of detailed hydrologic characterization tests - FY 2003. PNNL-14804, Pacific Northwest National Laboratory, Richland, Washington.

Spane FA, Jr, PD Thorne, and DR Newcomer. 2001a. Results of detailed hydrologic characterization tests - FY 1999. PNNL-13378, Pacific Northwest National Laboratory, Richland, Washington.

Spane FA, Jr, PD Thorne, and DR Newcomer. 2001b. Results of detailed hydrologic characterization tests - FY 2000. PNNL-13514, Pacific Northwest National Laboratory, Richland, Washington.

Spane FA, Jr, PD Thorne, and DR Newcomer. 2002. Results of detailed hydrologic characterization tests - FY 2001. PNNL-14113, Pacific Northwest National Laboratory, Richland, Washington.

Spane FA, Jr, PD Thorne, and DR Newcomer. 2003a. Results of detailed hydrologic characterization tests - FY 2002. PNNL-14186, Pacific Northwest National Laboratory, Richland, Washington.

Spane FA, Jr, JJ Butler, MD White, and TJ Gilmore. 2003b. Improving pulse/slug interference tests for contaminated site hydraulic property characterization. SERDP Fiscal Year 2004 Research Proposal, submitted February 25, 2003.

Springer RK, and LW Gelhar. 1991. "Characterization of large-scale aquifer heterogeneity in glacial outwash by analysis of slug tests with oscillatory response, Cape Cod, Massachusetts.” In: U.S. Geological Survey Water Resources Investigations. Report 91-4034:36-40.

Thorne PD, MA Chamness, FA Spane, Jr., VR Vermeul, and WD Webber. 1993. Three-dimensional conceptual model for the Hanford Site unconfined aquifer system, FY 93 status report. PNL-8971, Pacific Northwest Laboratory, Richland, Washington. 
Zubruchen BR, VA Zlotnik, and JJ Butler, Jr. 2002. "Dynamic interpretation of slug tests in highly permeable aquifers.” Water Resources Research, 38(3): 7:1-18. 
Appendix A

\section{Slug Test Field Notes}




\section{Appendix A: Slug Test Field Notes}

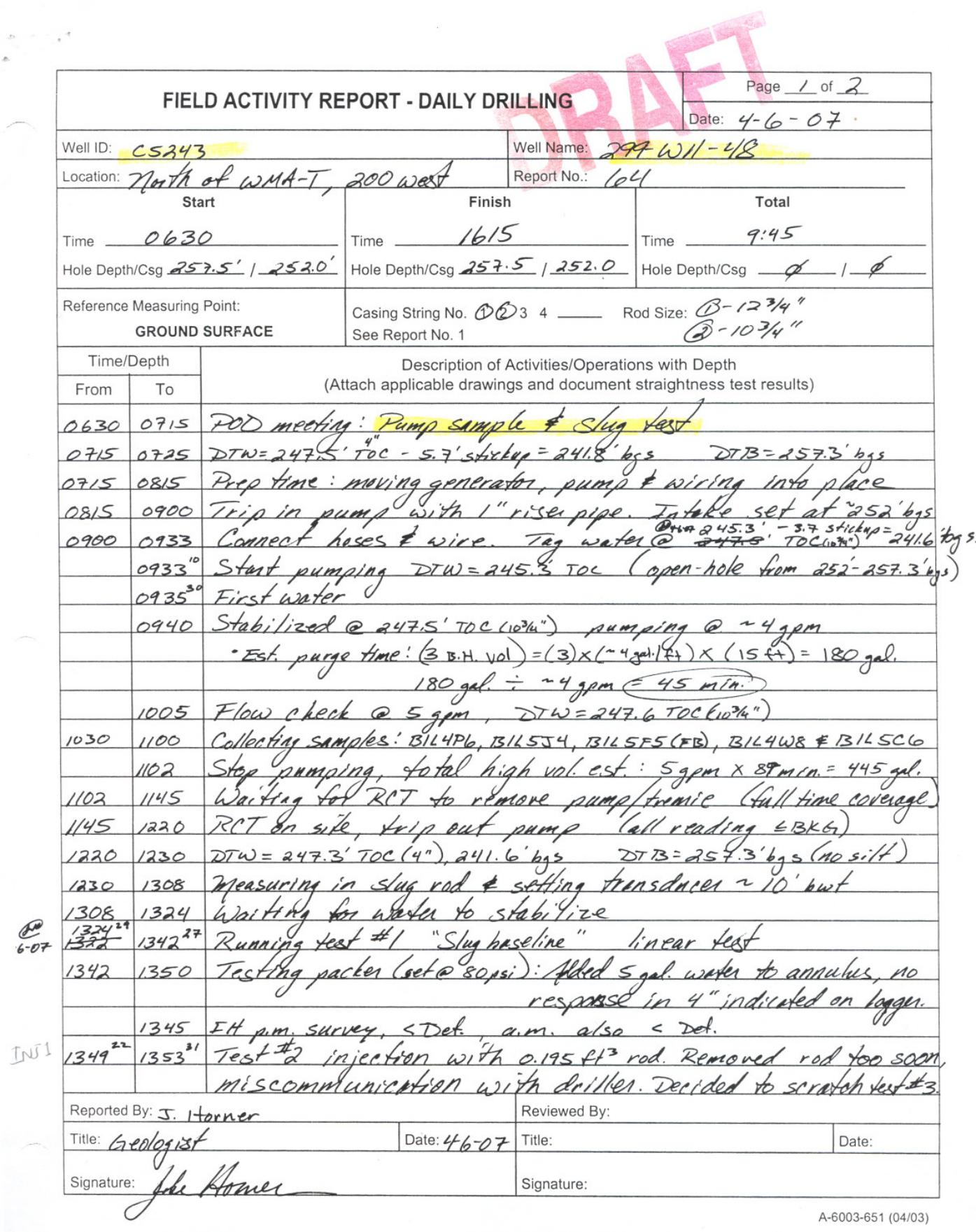

A.1 


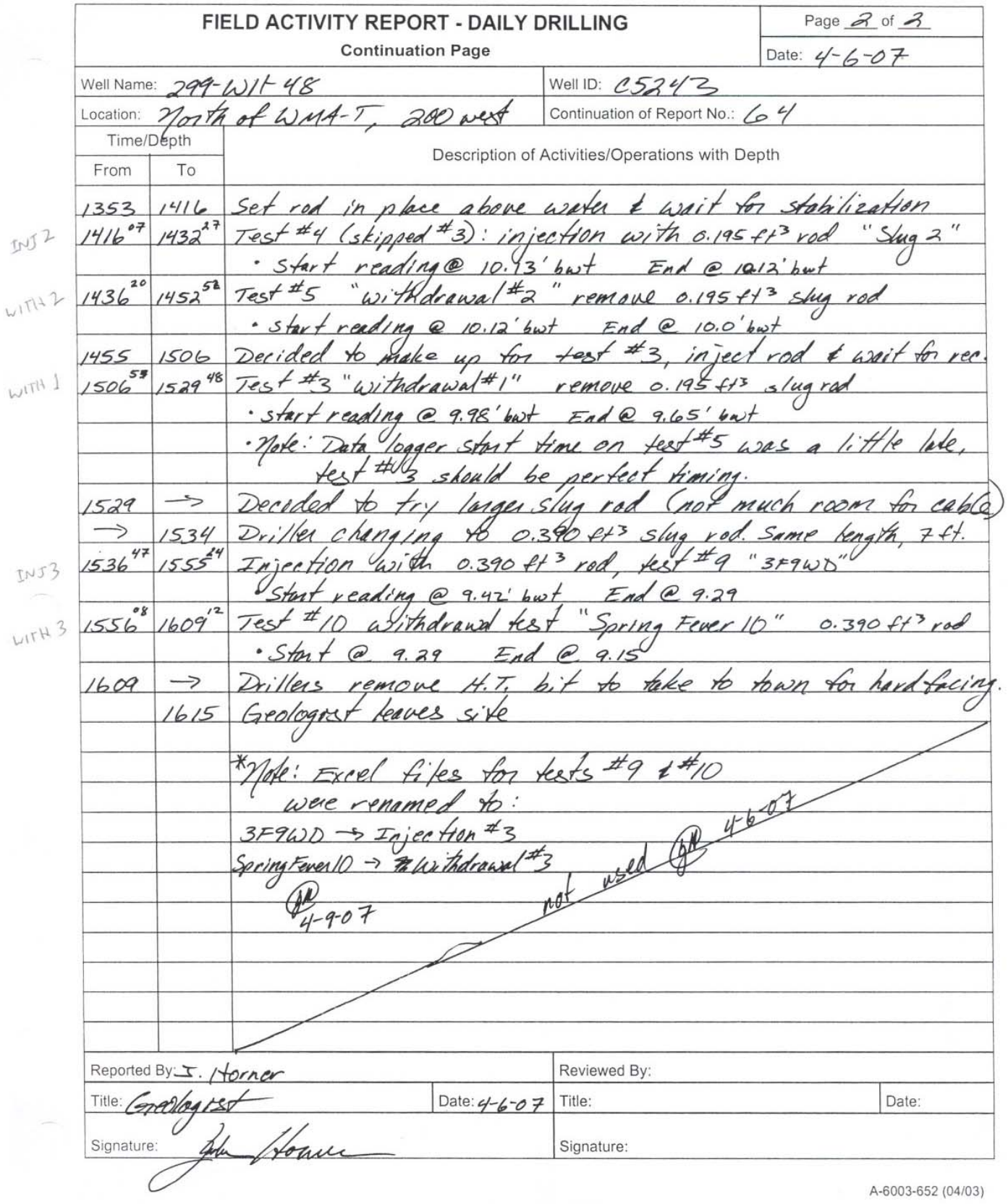




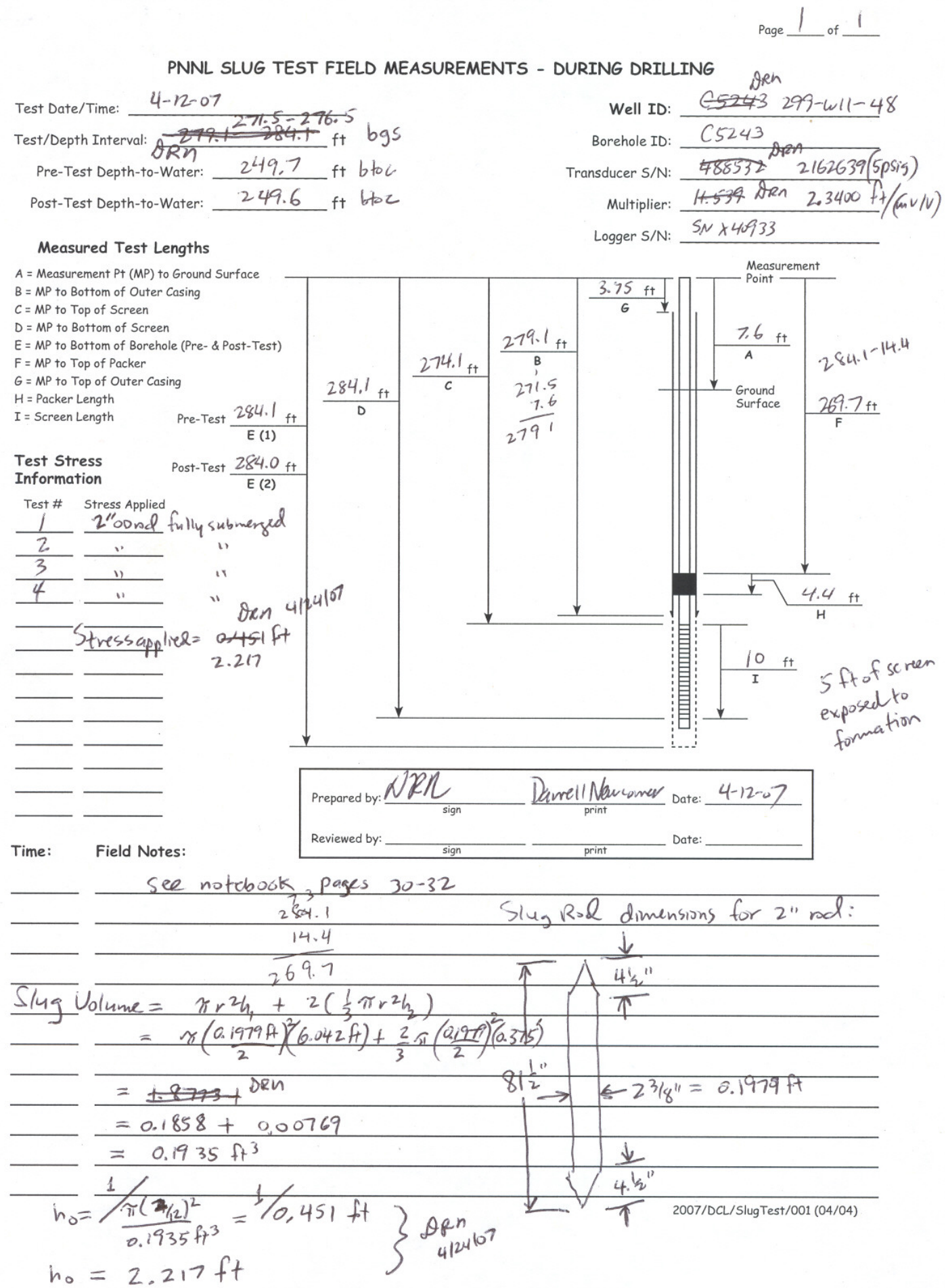

A.3 


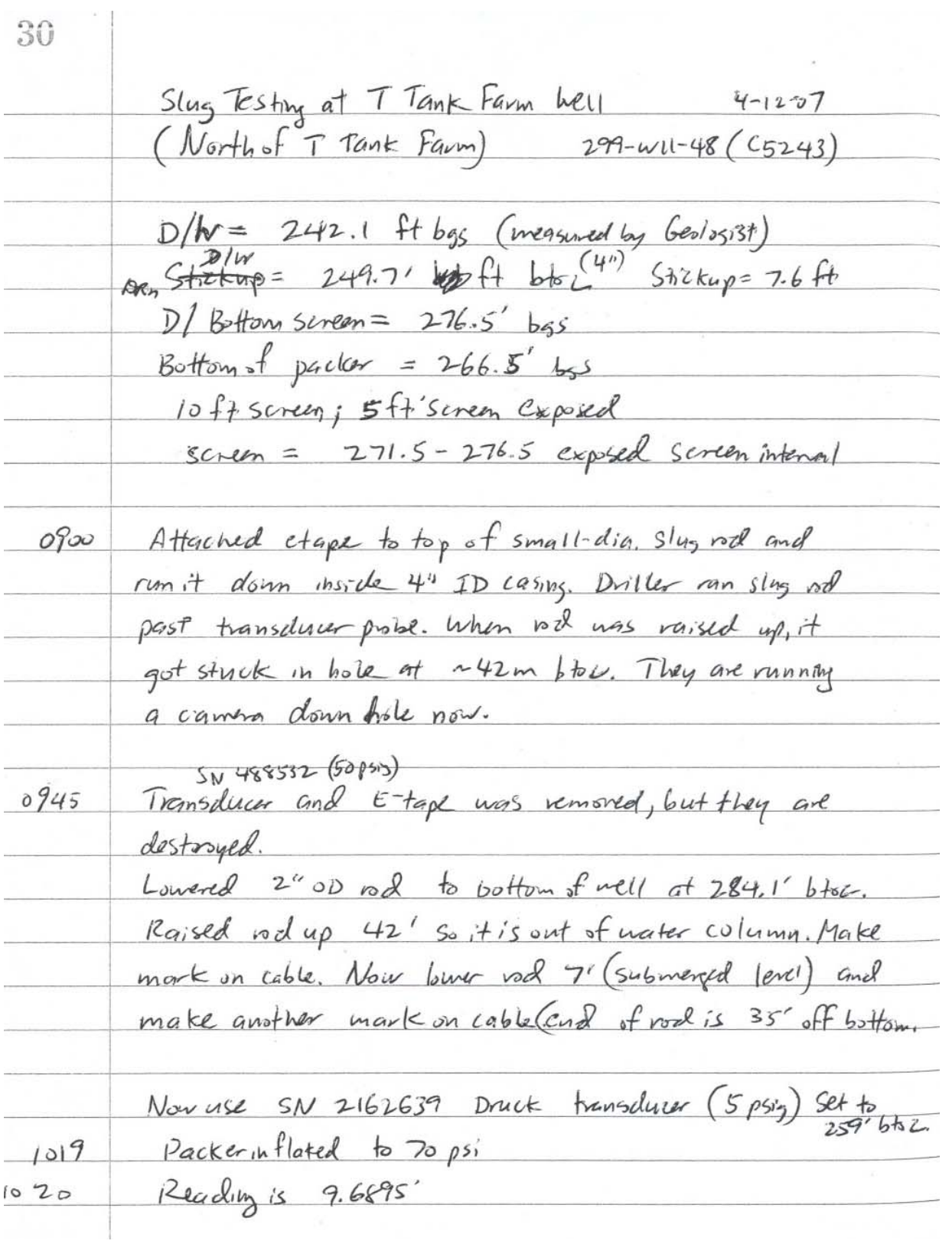




$$
\text { well 299-w11-48 (c5243) 4-1207 }
$$

ion Initiake Test 1 l, but little or no response.

1055 Large slugrod will not go past ist juint at 5 'btor, because 4"IP casing is not straight. We'll repeat tests with small slug rd.

Duniy sampling, Q was $215 \mathrm{gpm}$ and there was no measurable draurdown, according to Gologist. They got very little testresponse in last set of sius tests $10 \mathrm{ft}$ higher
2"OD od 1106 Initiake slug withdrawal test \#2, i-2 see to completely withdram slug od. $\quad \Delta t=0.5 \mathrm{sec}$.

1108 Transducer readins changed abmetly for no apparent reasun.

1111 Lover rad into water column

1120 Champ st to $0.25 \mathrm{sec}$

i120:30 Test \#3 (slugwithdrawal test with 2"OD rod)

1122.40 Loner red back dome into water column

1130 Test 144 ; Sluguitudramal with 2 "OD red

There is a wuchslowt test responce now.

1136 Packerpressune still at 70psi

1138:50 Conduct packer intesnity test-pour $5 \mathrm{gal}$ of cleam water

down unulus between $4 "$ inninercasiy and outercasing.
1139.40 Finished pouring 5 gad.
1141 Appears to be no response, so packer is hoalding fine 


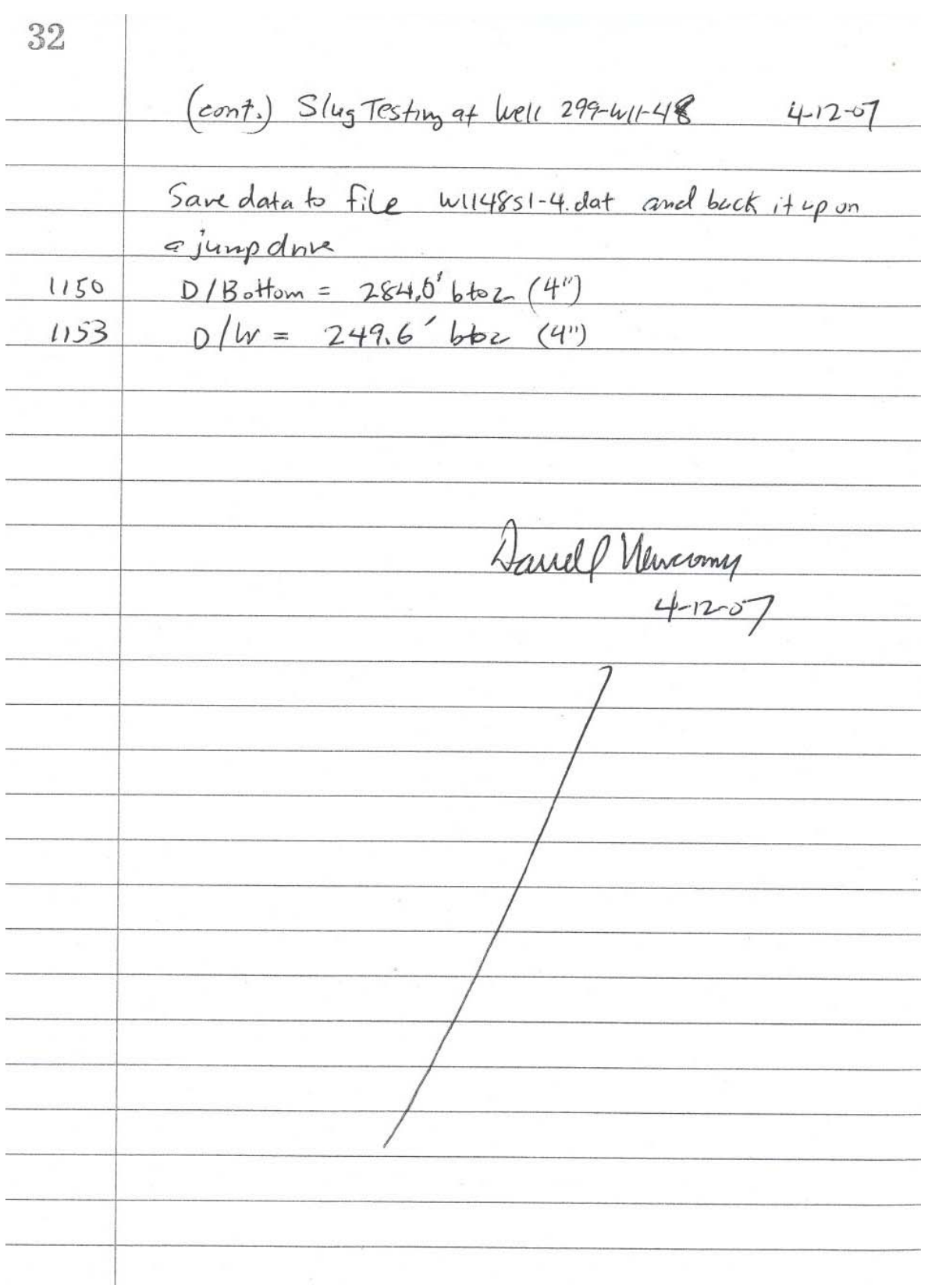




$$
\text { Page } 1 \text { of } 4
$$

PNNL SLUG TEST FIELD MEASUREMENTS - DURING DRILLING
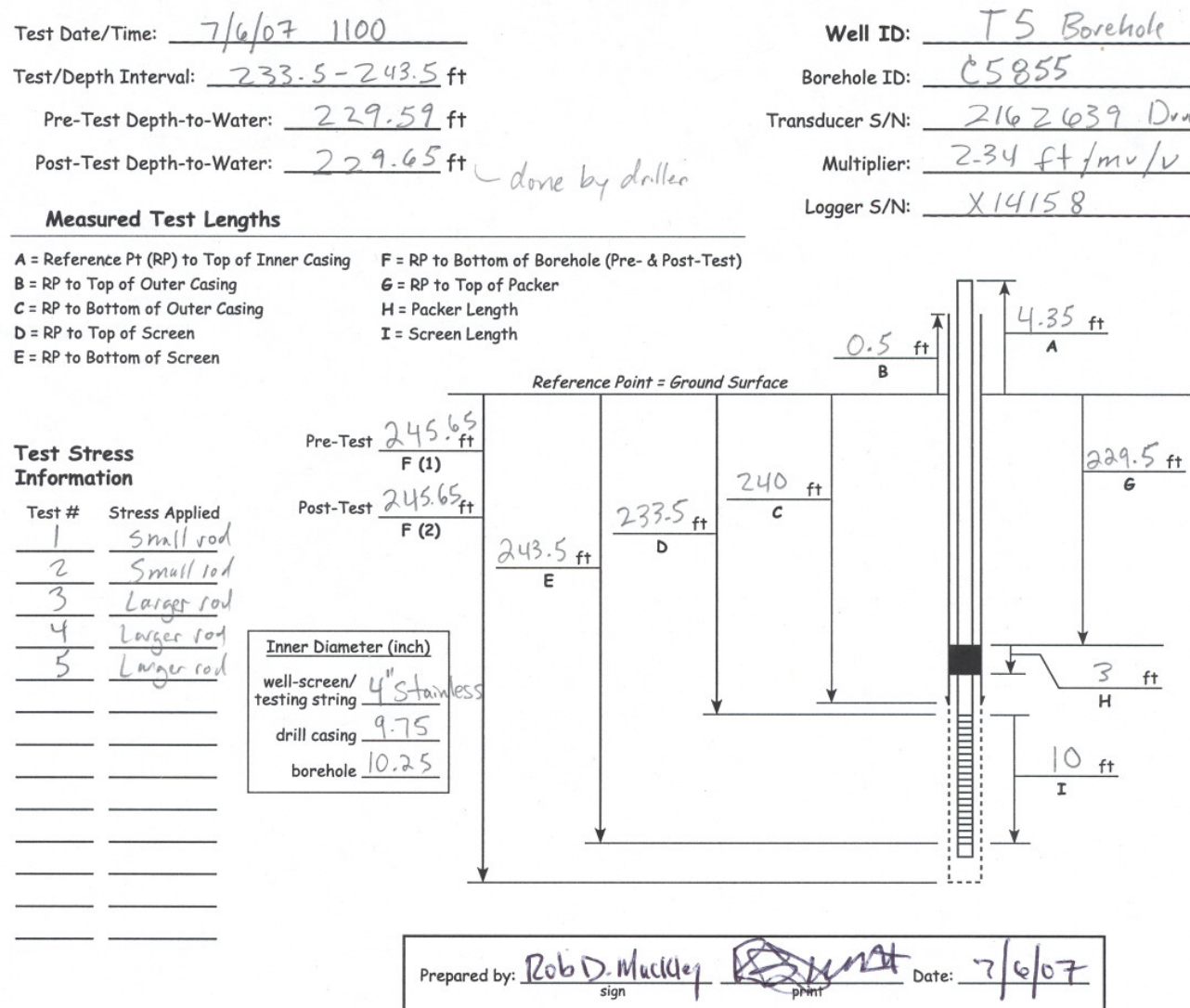

Reviewed by:

1120 Colgist (JessHawkins) has notes stating D/W(BGS) of 229.6'@07217667.

1 "Snnall" sluging soul is $25 / 16$ "OD 81 "long wl tapers At Bothends. 0.195 stamp.

$\checkmark$ "Lagget" Sluggm rod is 23 " OD 81 "long w tapers At Both ends. No strup.

$1125 \quad D / B=245.65 \mathrm{BGS} \quad D / \omega=229.59$

1130 Made morks on cable-tool rig cable w/ chalk P submerged And un submerged

1 depths; Rod submerged 21 'Below water table, Rod Suspended a I'above

1137 Water table.

1145 Pour 5 gallon clean $\mathrm{H}_{2} \mathrm{O}$ down annulus to verif packer seal jassed-

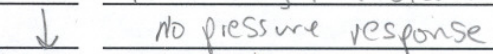

1151 Lowered small slug rod in to water (1.74' increase initiall-then stablized) 2007/DCL/S/ugTest/001 (05/04) 
Page 2 of 4

PNNL SLUG TEST FIELD MEASUREMENTS - DURING DRILLING

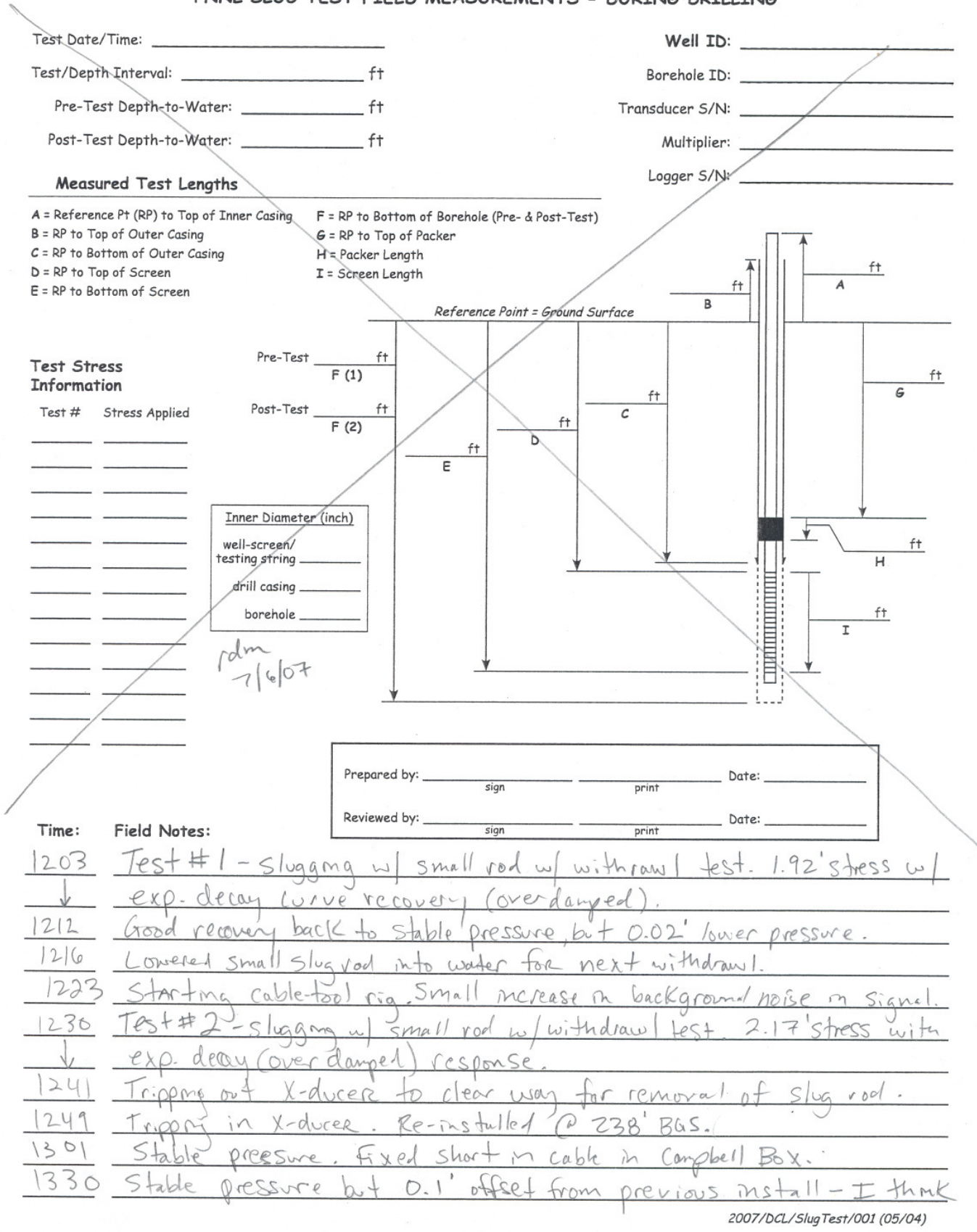


PNNL SLUG TEST FIELD MEASUREMENTS - DURING DRILLING

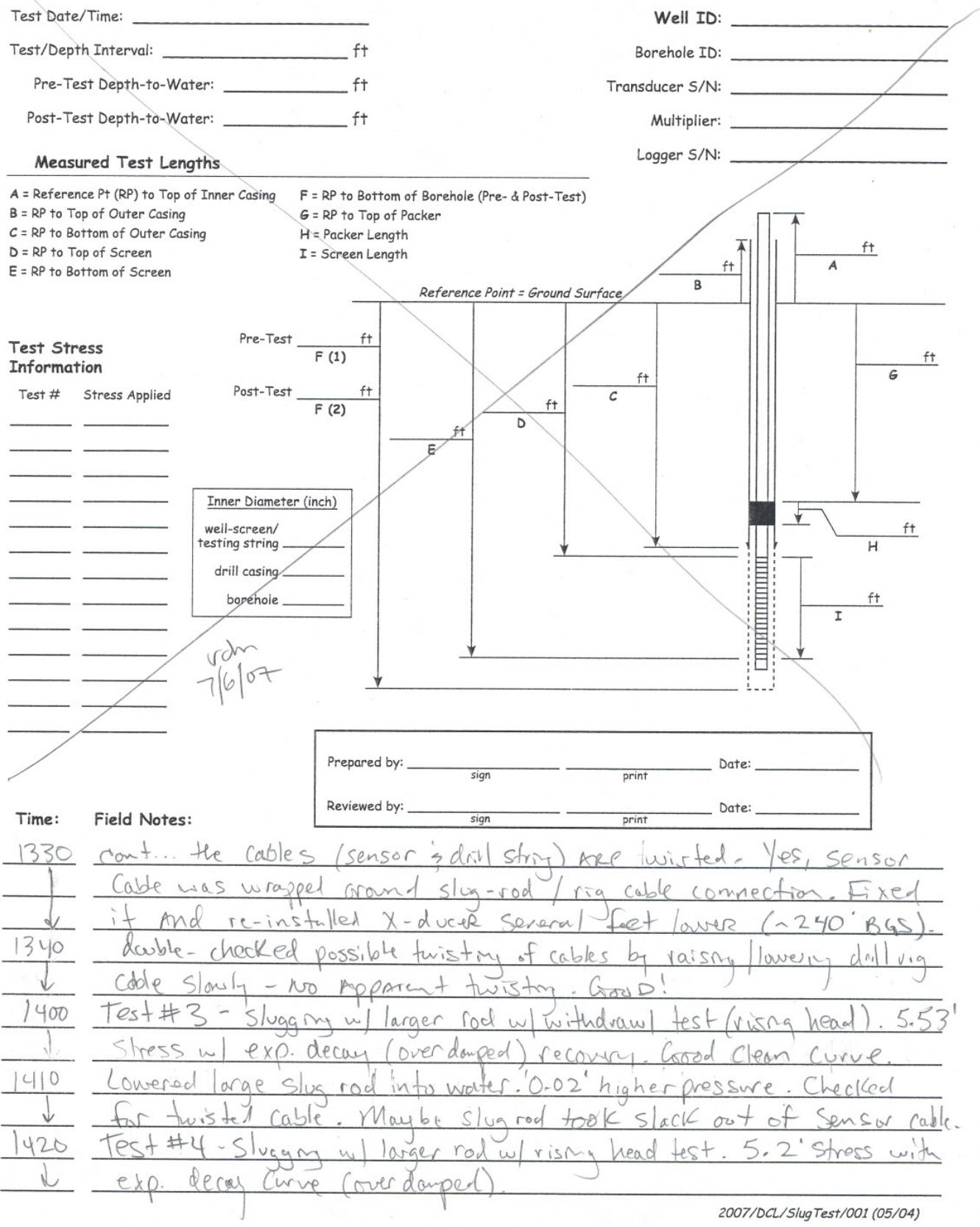


PNNL SLUG TEST FIELD MEASUREMENTS - DURING DRILLING

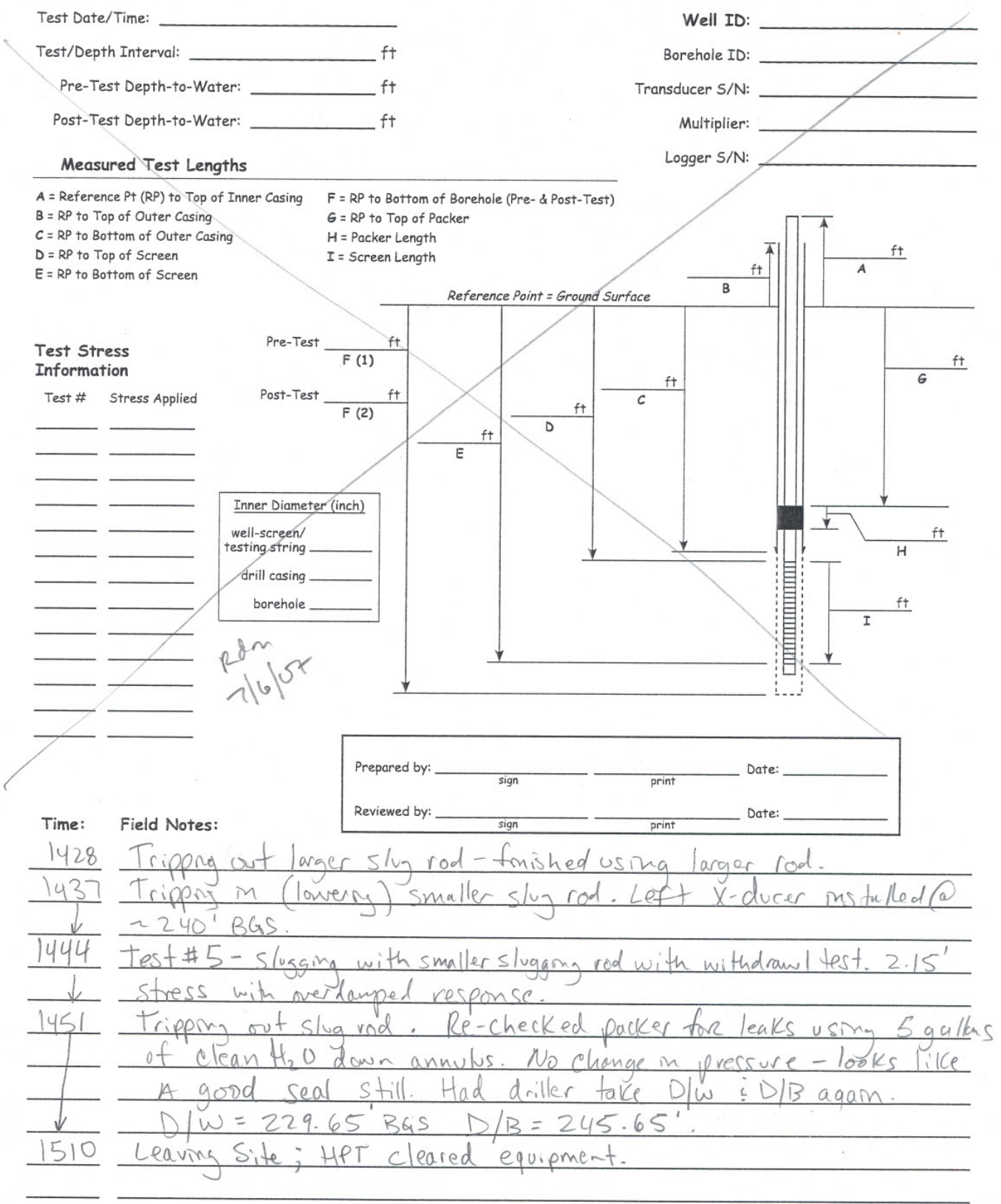

2007/DCL/SlugTest/001 (05/04) 
Appendix B

Selected Borehole Logs 


\section{Appendix B: Selected Borehole Logs}

Figure B.1 Well 299-W11-48

Borehole Log for Well 299-W10-33 not available.

B.1 


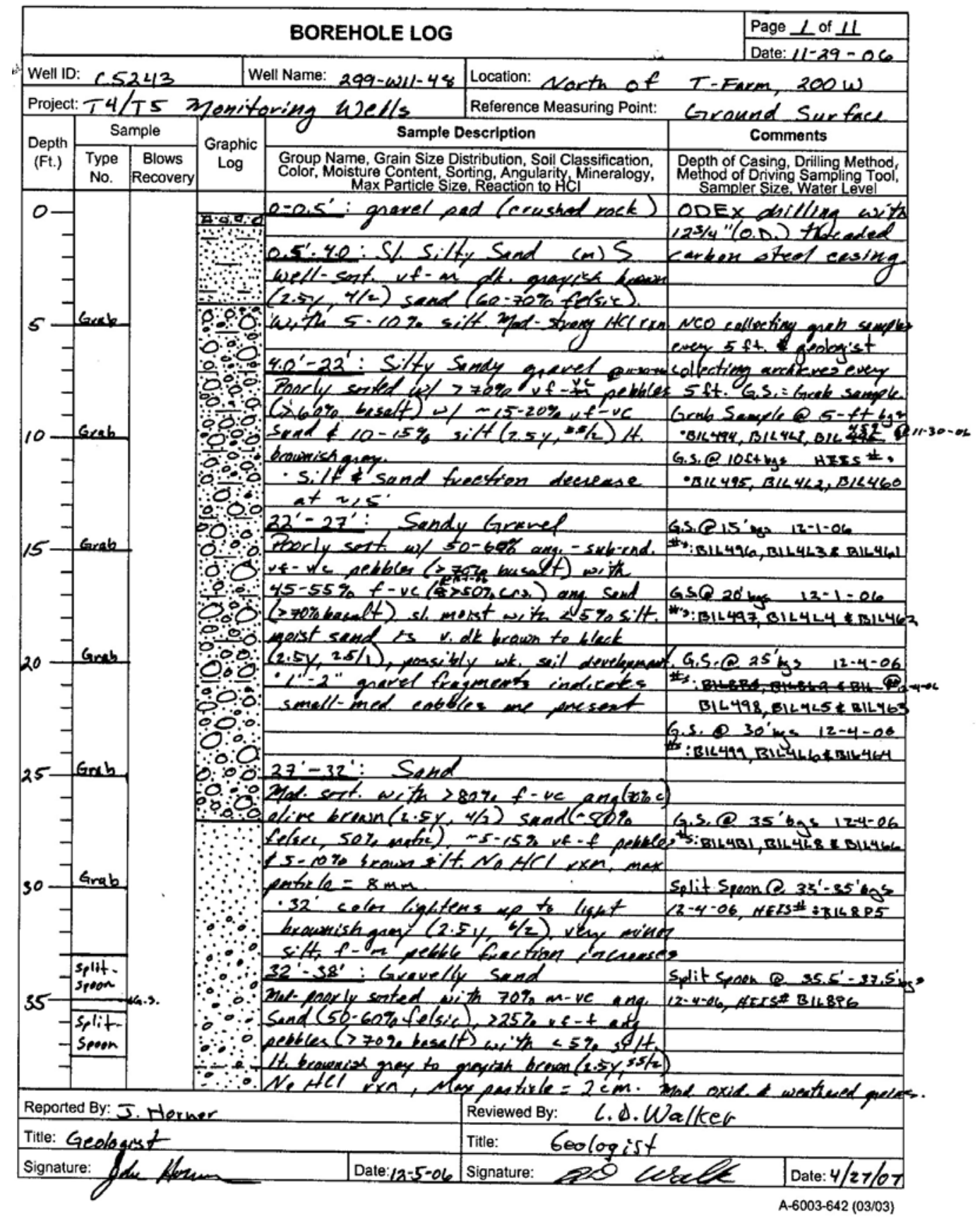

B. 2 


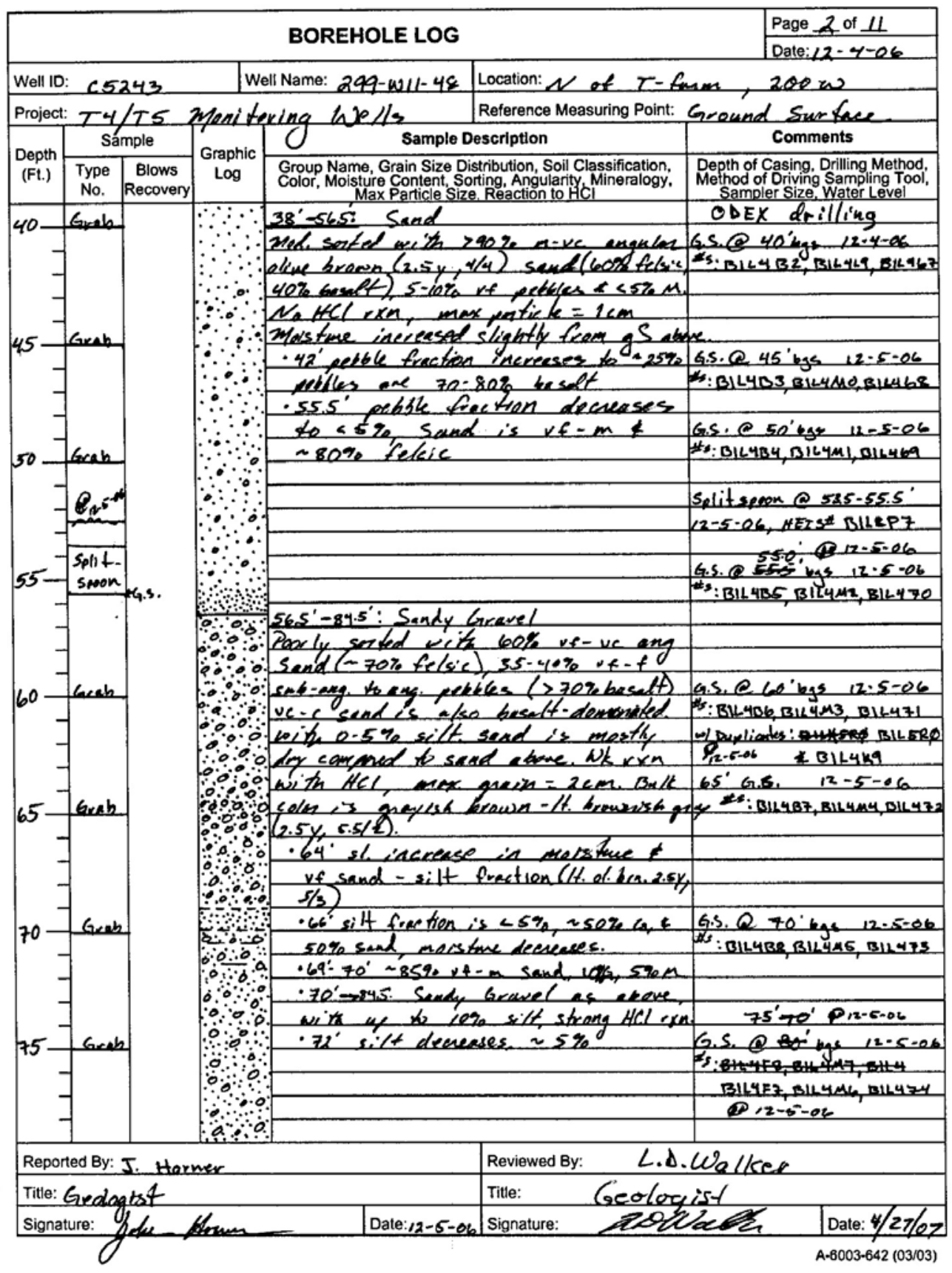




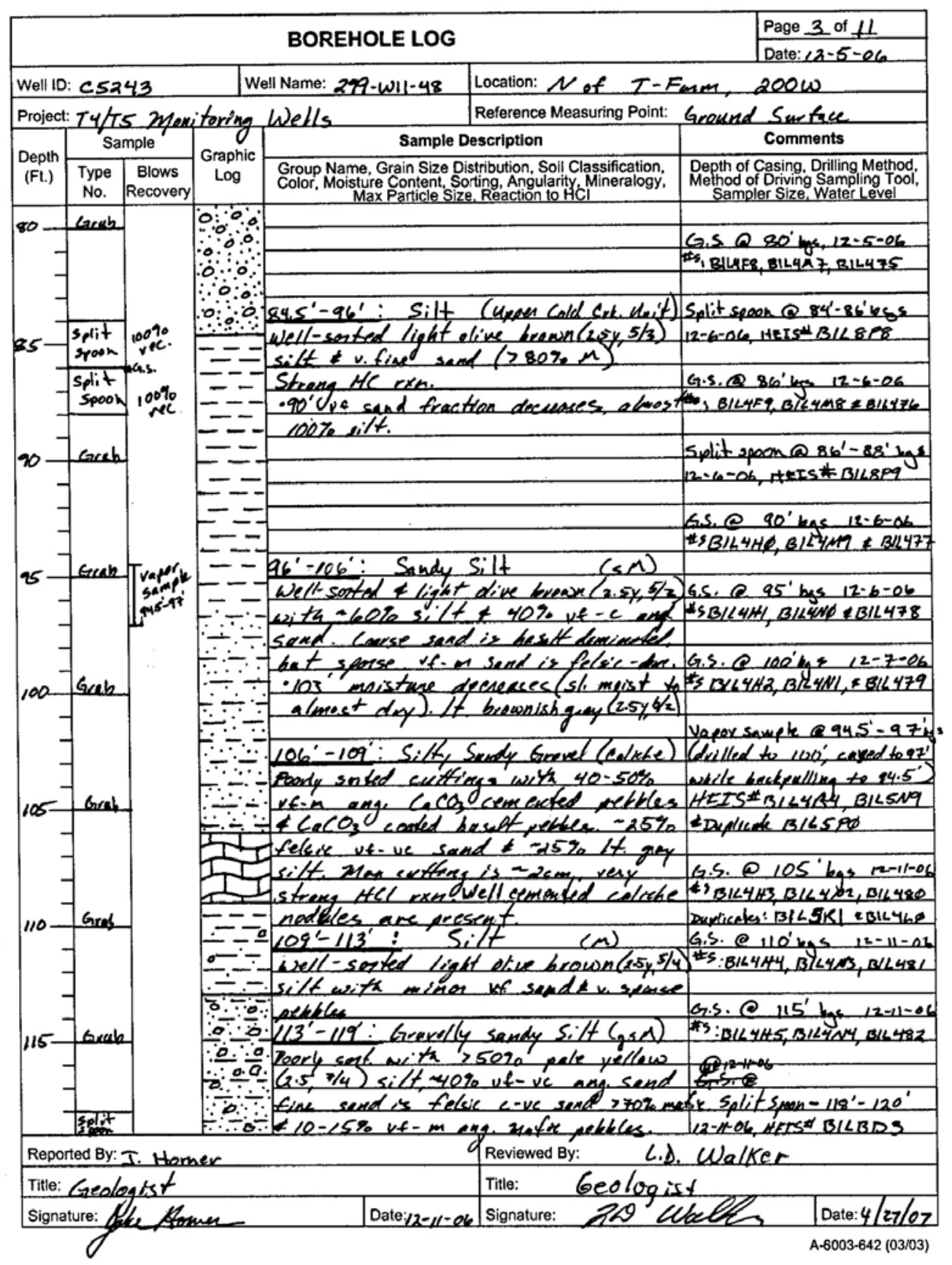




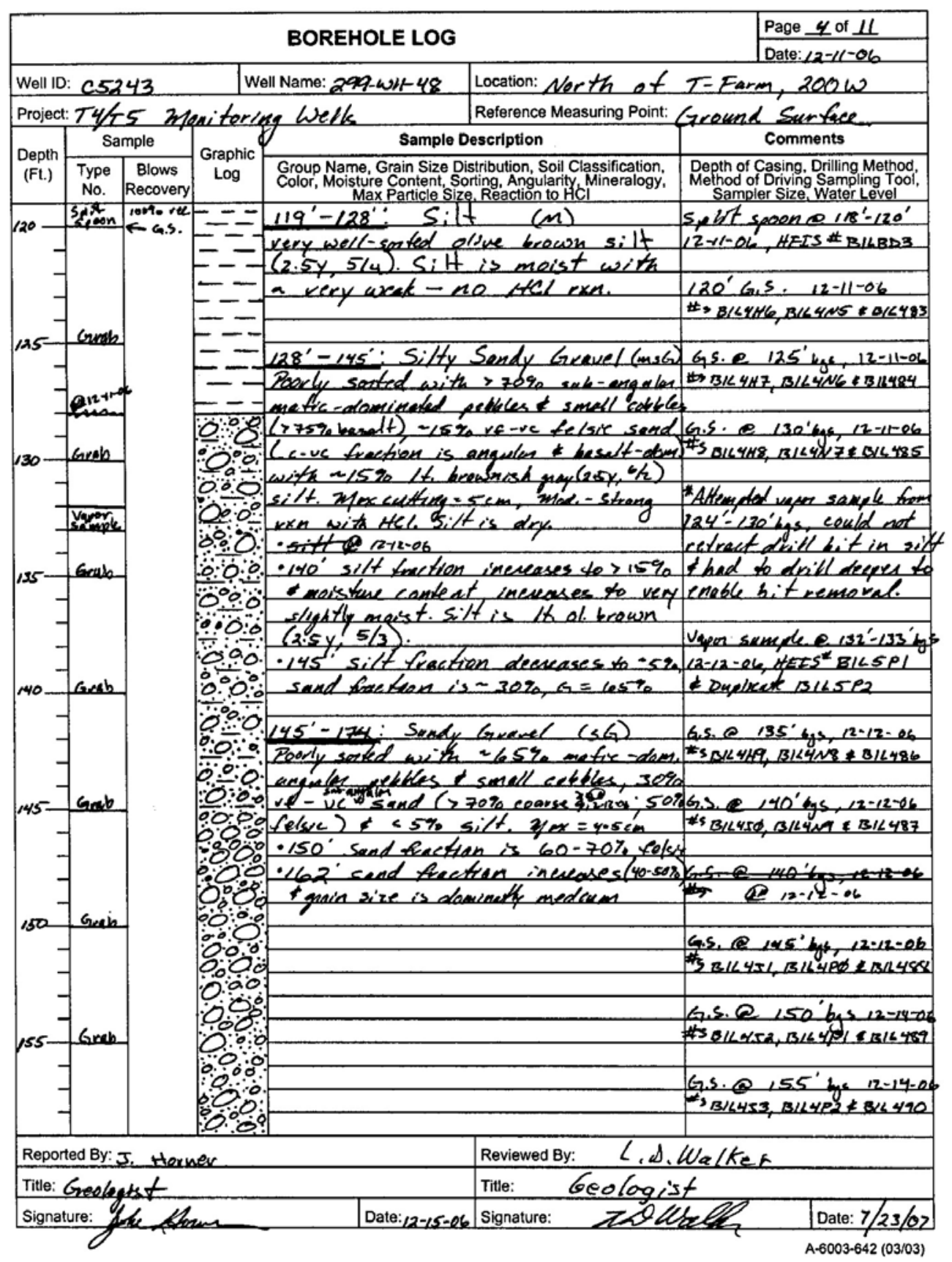




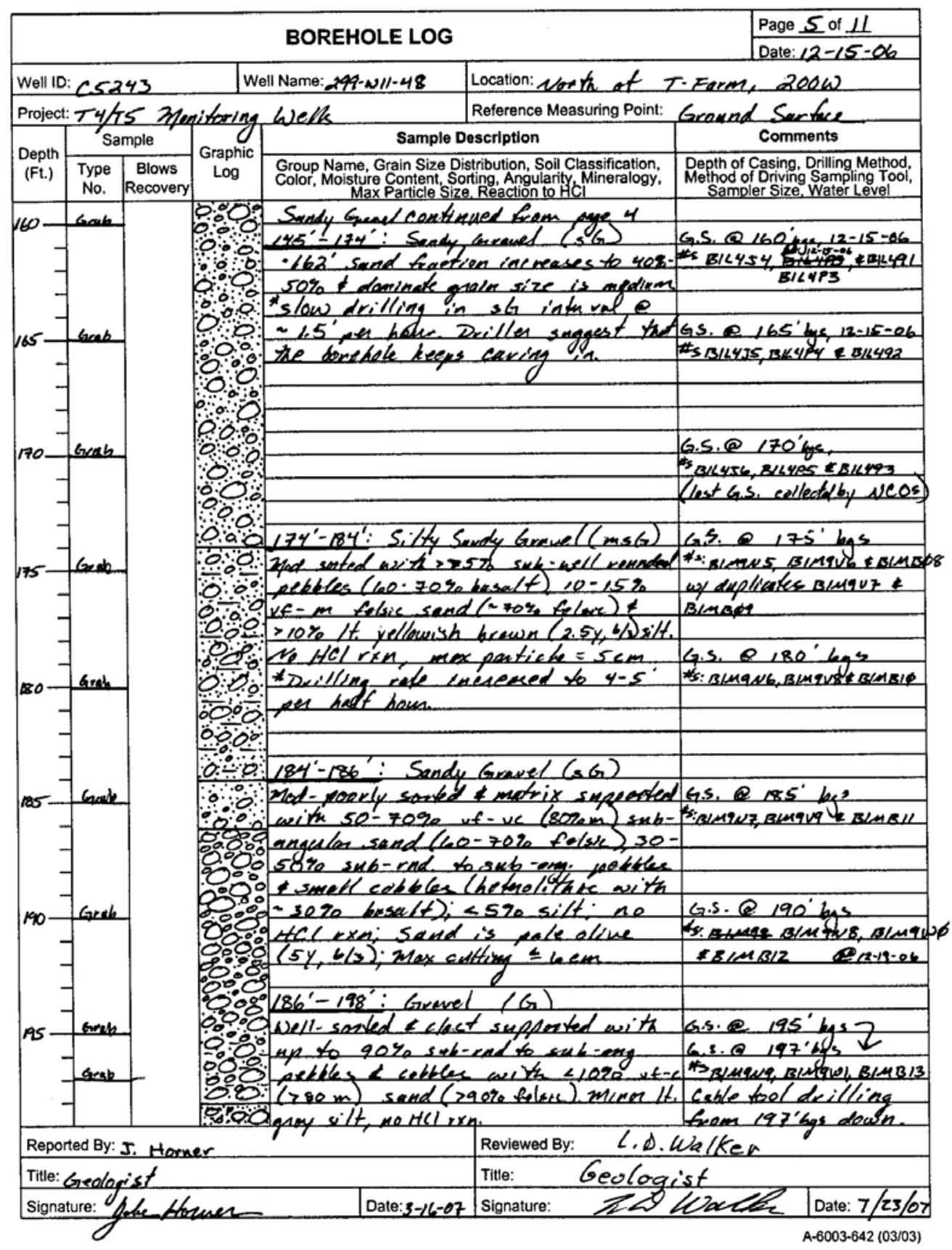




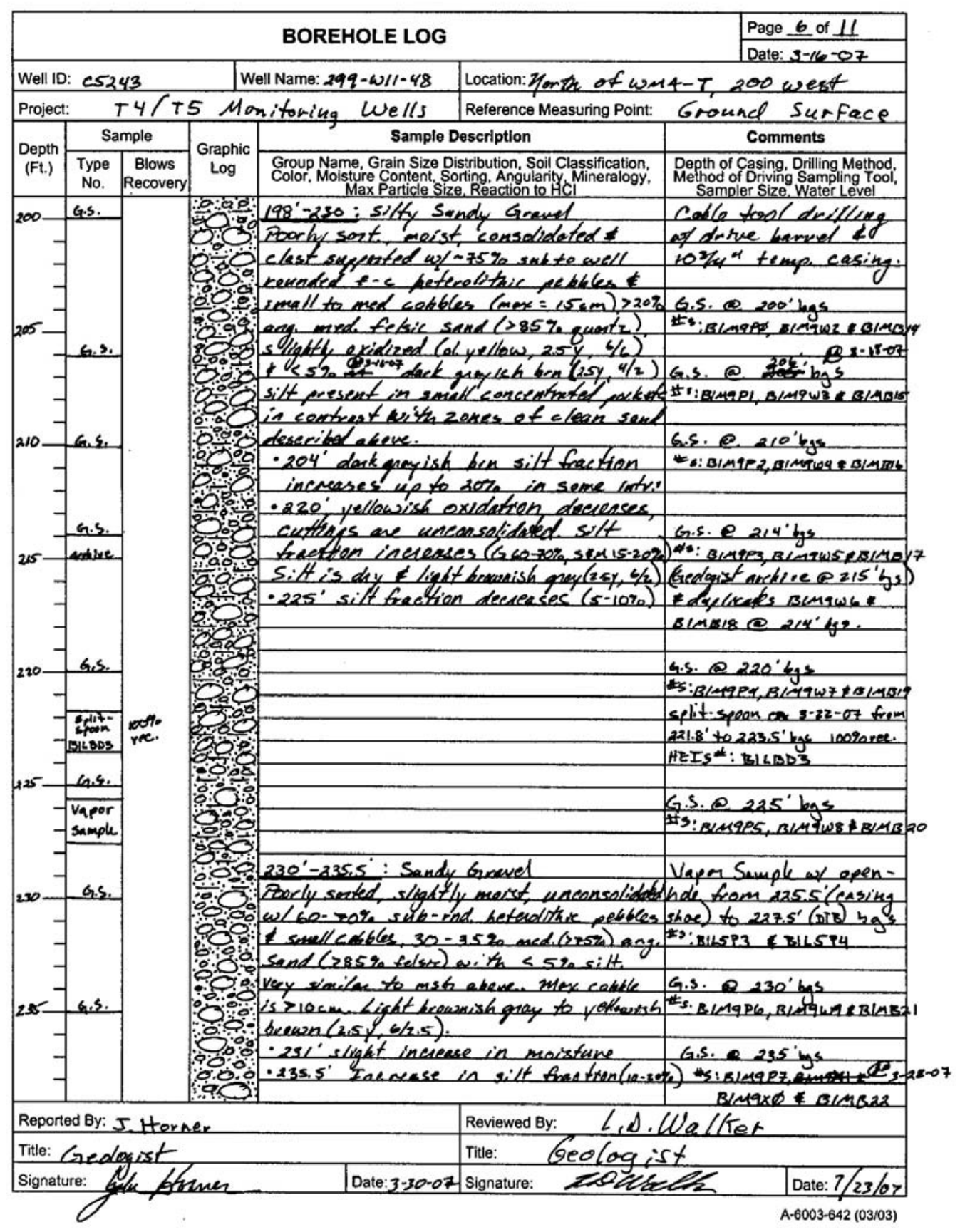




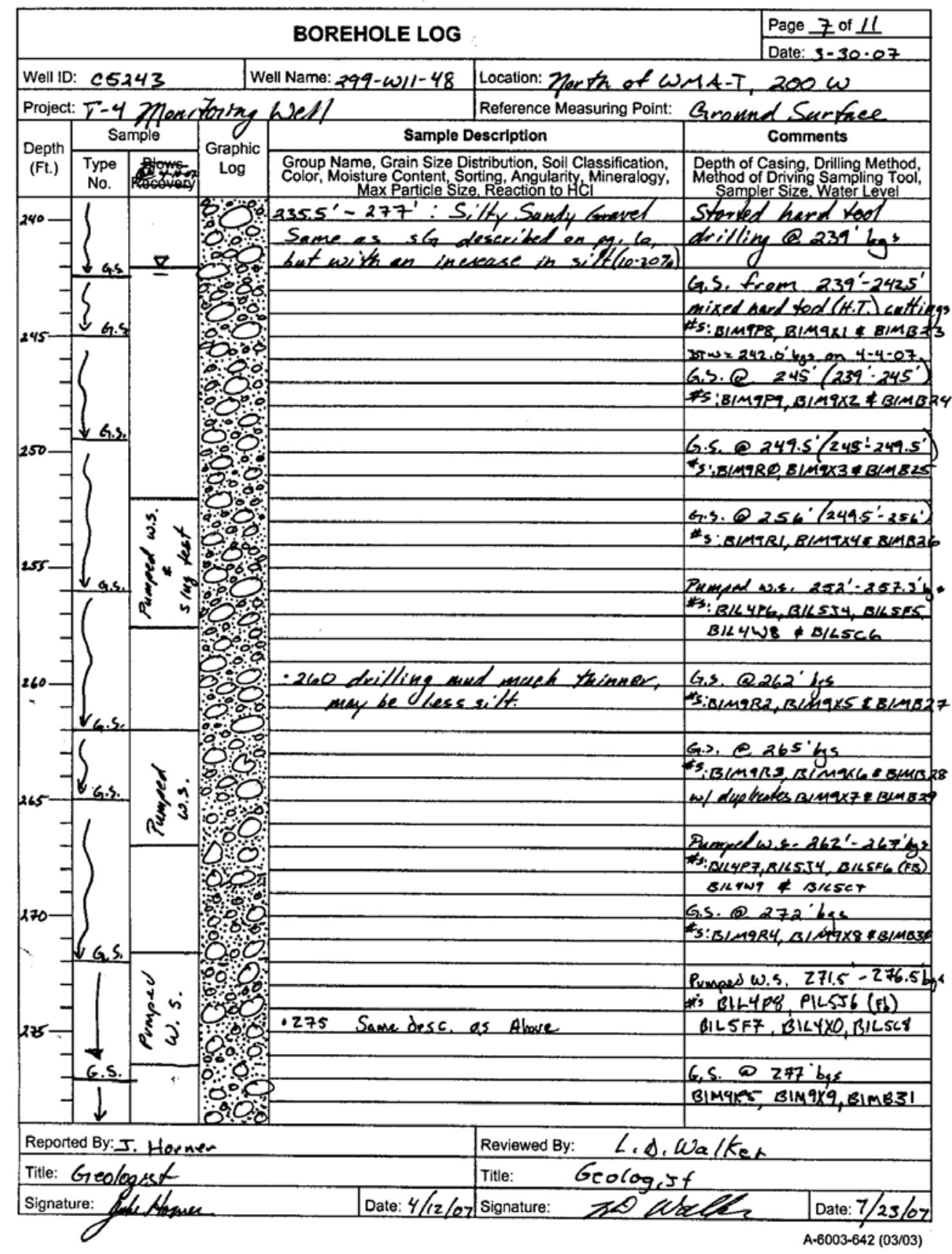

B. 8 


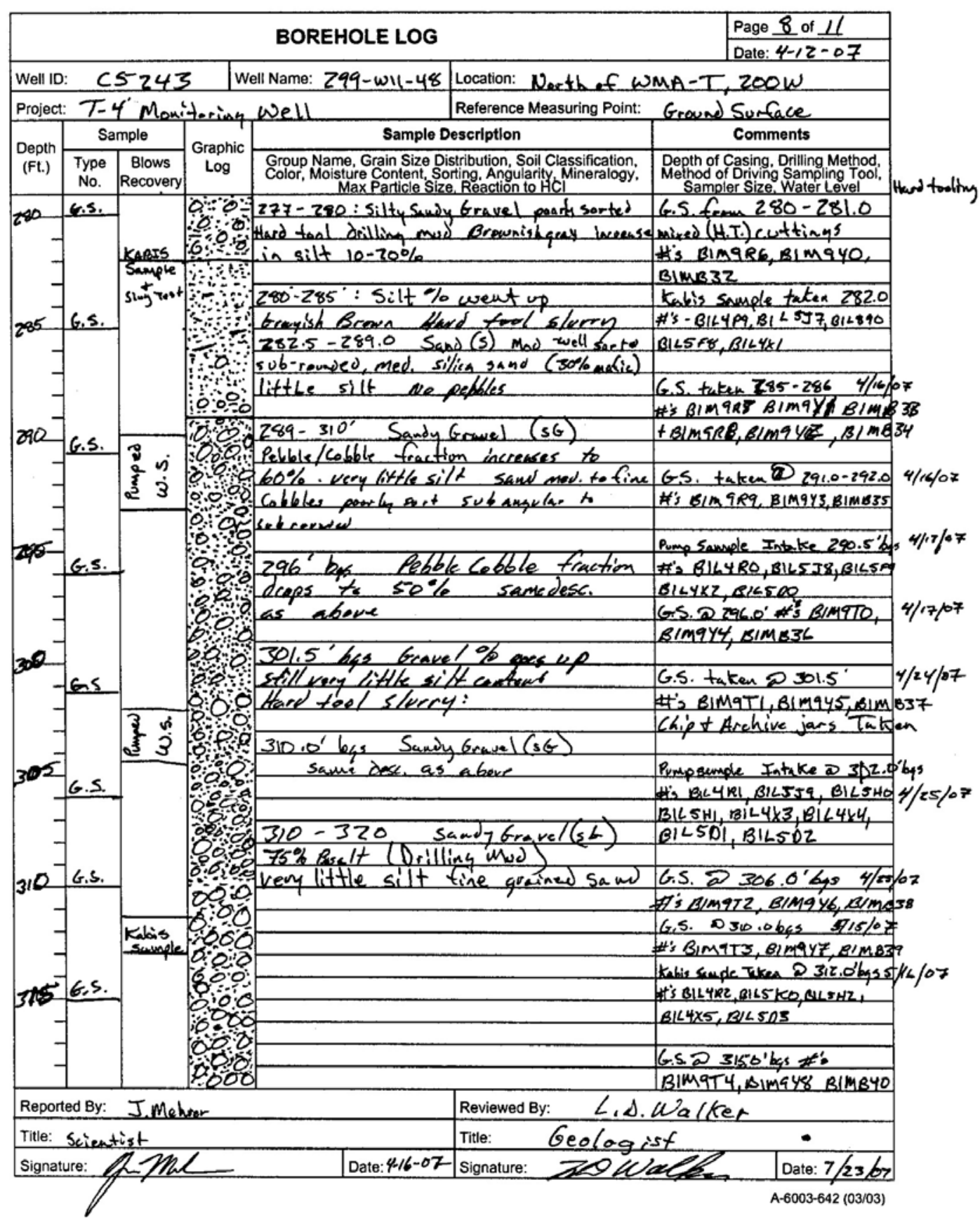




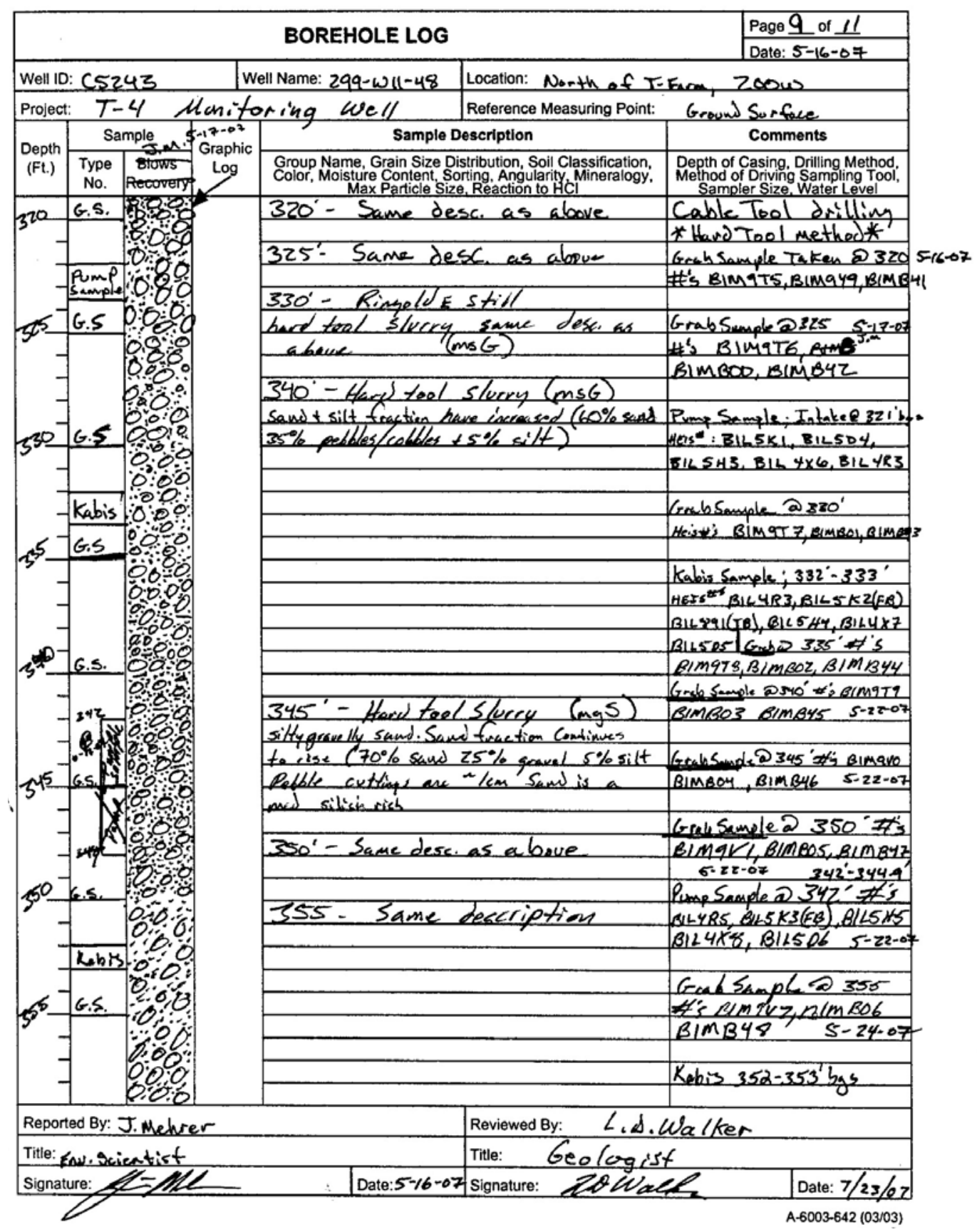




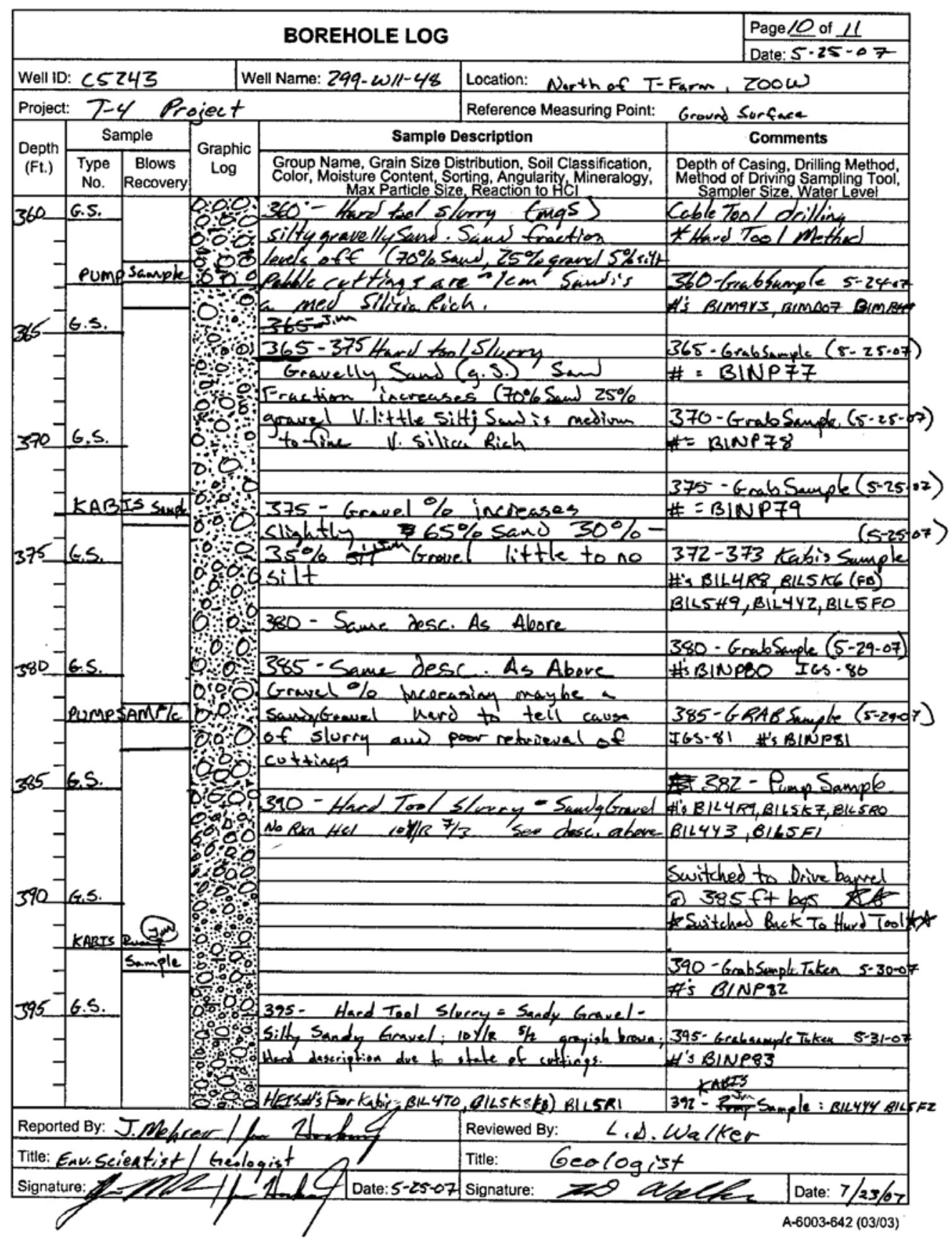

B.11 


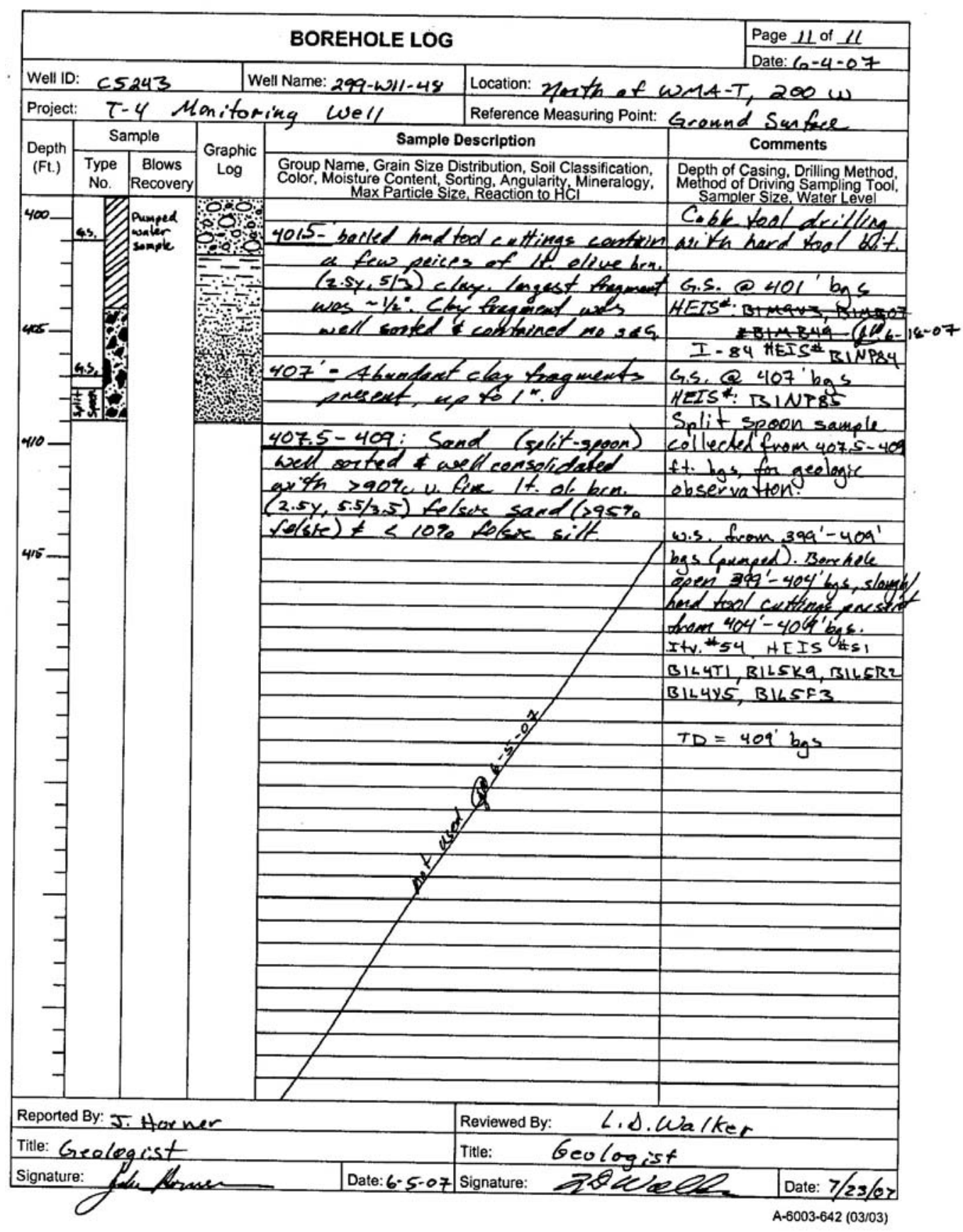

B.12 
PNNL-16945

\section{Distribution}

\section{ONSITE}

Pacific Northwest National Laboratory

P. E. Dresel

J. S. Fruchter

F. A. Spane

Fluor Hanford, Inc.

J. V. Borghese

M. E. Byrnes

D. B. Erb

D. G. Horton

S. P. Luttrell

V. J. Rohay

C. Sutton

L. C. Swanson

B. A. Williams

C. S. Wright

\section{ONSITE}

CH2M Hill Hanford Group, Inc.

F. J. Anderson

M. Connelly

W. J. McMahon

U.S. Department of Energy-

Richland Operations

J. G. Morse

A. C. Tortoso

Vista Engineering

W. Bratton

Distr. 1 